\title{
SOLAR ARCTIC-MEDIATED CLIMATE VARIATION ON MULTIDECADAL TO CENTENNIAL TIMESCALES: EMPIRICAL EVIDENCE, MECHANISTIC EXPLANATION, AND TESTABLE CONSEQUENCES
}

\author{
Willie W.-H. Soon \\ Harvard-Smithsonian Center for Astrophysics \\ Cambridge, Massachusetts 02138
}

\begin{abstract}
Soon (2005) showed that the variable total solar irradiance (TSI) could explain, rather surprisingly, well over $75 \%$ of the variance for the decadally smoothed Arctic-wide surface air temperature over the past 130 years. The present paper provides additional empirical evidence for this physical connection, both through several newly published high-resolution paleo-proxy records and through robust climate-process modeling outputs. This paper proposes a mechanistic explanation, involving: (1) the variable strength of the Atlantic meridional overturning circulation (MOC) or thermohaline circulation (THC); (2) the shift and modulation of the Inter-Tropical Convergence Zone (ITCZ) rainbelt and tropical Atlantic ocean conditions; and (3) the intensity of the wind-driven subtropical and subpolar gyre circulation, across both the North Atlantic and North Pacific. A unique test of this proposed solar TSI-Arctic thermal-salinity-cryospheric coupling mechanism is the 5- to 20-year delay effect on the peak Atlantic MOC flow rate centered near $30-35^{\circ} \mathrm{N}$, and on sea surface temperature (SST) for the tropical Atlantic. The solar Arctic-mediated climate mechanism on multidecadal to centennial timescales presented here can be compared with and differentiated from both the related solar TSI and UV irradiance forcing on decadal timescales. The ultimate goal of this research is to gain sufficient mechanistic details so that the proposed solar-Arctic climate connection on multidecadal to centennial timescales can be confirmed or falsified. A further incentive is to expand this physical connection to longer, millennial-scale variability as motivated by the multiscale climate interactions shown by Braun et al. (2005), Weng (2005), and Dima and Lohmann (2009). [Key words: solar-Arctic climate connection, total solar irradiance, Atlantic meridional overturning circulation, climate variability.]
\end{abstract}

\section{THE SOLAR ARCTIC-MEDIATED CLIMATE VARIATION ON MULTIDECADAL TO CENTENNIAL TIMESCALES}

Paleoclimatic proxies show ubiquitous, multidecadal to centennial-scale variabilities that may ultimately be associated with the persistent forcing by solar irradiance variability as properly projected and amplified through the annual progression of the Earth around the Sun (Table A1, Appendix). The present study indirectly assumes the optimal climatic response filter of the Earth ocean-atmosphere-ice system to peak around such multidecadal to centennial scales, which can be taken to be roughly 50 to 500 years (i.e., much less than 1000 years). The challenge of this research, then, must lie in the identification of relevant and/or dominant centers of climatic action (COAs; Table 1 lists acronyms used in this paper) and interactions among those COAs (Christoforou and Hameed, 1997; Rodionov et al., 2005; Huth et al., 2006; Lim et al., 2006). Huth et al. (2006) found a general tendency for atmospheric circulation modes ${ }^{1}$ to be more zonal, with COAs covering wider areas and 
Table 1. List of Acronyms Used in This Paper

\begin{tabular}{ll}
\hline \hline \multicolumn{1}{c}{ Acronym } & \multicolumn{1}{c}{ Definition } \\
\hline TSI & total solar irradiance \\
UV & ultraviolet \\
BP & Before Present \\
COAs & centers of (Climatic) action \\
SST & sea surface temperature \\
SLP & sea level air pressure \\
EPG & equator-to-pole surface temperature gradient \\
AMO & Atlantic Multidecadal Oscillation \\
NPMO & North Pacific Multidecadal Oscillation \\
PDO & Pacific Decadal Oscillation \\
NAO & North Atlantic Oscillation \\
ENSO & El Nino-Southern Oscillation \\
MOC & meridional overturning circulation \\
THC & thermohaline circulation \\
ISOW & Iceland-Scotland Overflow Water \\
GIN Seas & Greenland-Icelandic-Norwegian Seas \\
ITCZ & Intertropical Convergence Zone \\
SPCZ & South Pacific Convergence Zone \\
GISP2 & Greenland Ice Sheet Project 2 \\
MIS & marine isotope stage \\
GCM & general circulation model \\
CMIP3 & Coupled Model Intercomparison Project Phase 3 \\
NCAR & National Center for Atmospheric Research \\
IPCC & United Nations Intergovernmental Panel on \\
& Climate Change \\
\hline
\end{tabular}

teleconnection among different regions spanning longer distances when solar activity is strong. The hard task of separating the dynamics of the teleconnection from the actual physical mechanisms at COAs must be kept in mind as well.

In this paper, climate refers to the systematic persistence of weather patterns and fluctuations that involve: (1) seasonal and annual cycles (i.e., not just time-averaged weather statistics); (2) local and regional air pressure systems; (3) topography, landscape, and the storage and exchange of heat/energy through atmospheric and oceanic circulation; and (4) delayed actions. All these persistent local and regional actions and variations take place prior to any global mean radiative forcing or any cohesive global mean temperature and precipitation responses. In other words, the weather-mediated climate variation and change will be viewed as local and regional "inter-seasonal" variations that cover time intervals from months and years to tens of millennia. The basic mechanisms involved are not unlike the original orbital theory of climate change by Milutin Milankovitch, published in the early 1940s, which emphasized high-latitude, light-sensitive COAs to explain globalscale glaciation and deglaciation events and transitions. A key emphasis of this insolation-weather-climate framework are the differential responses at different latitudes to insolation changes (Davis and Brewer, 2009) in addition to responses arising from effects of the four seasons. Thus, it is suggested that persistent insolation forcing, when maintained over multidecadal to centennial timescales, accounting for both the systematics of the Sun-Earth orbital geometry (Loutre et al., 1992) and 
the irradiance variability intrinsic to magnetic variation of the Sun (e.g., Soon, 2007), is both necessary and sufficient to explain the observed climatic variation on multidecadal to centennial timescales.

It can be further added that an all-inclusive theory of climate change should also account for the newly proposed theory of independent hemispheric responses to solar forcing by Huybers and Denton (2008), whereby a Northern Hemispheric response is sensitive to both the local summer insolation intensity and the latitudinal insolation and temperature gradients (Davis and Brewer, 2009), while a Southern Hemispheric response is more sensitive to local summer duration.

In the framework of climatic forcings and responses, an understanding of both the spectral peaks and the seemingly gap-less continuum of weather-climate operation will be sought. Huybers and Curry (2006) recently re-initiated such research by seeking to connect the annual and Milankovitch cycles to the in-between continuum temperature variability in terms of the response to deterministic insolation forcing. Coincidentally, the multidecadal to centennial timescales discussed in the present study are similar to the recognized transitional timescale of Huybers and Curry (2006), who proposed that the annual cycle, with assistance from the oceanstorage delays, served to extend the continuum temperature variability from months to decades, while the Milankovitch orbital forcing cycles, with assistance from nonlinear ice-sheet dynamics, drove the continuum temperature variability to higherfrequency timescales of millennia.

This view of local and regional origins of wide spatial climatic co-variations and responses is consistent with the emphasis on relatively high net solar radiation reaching the surface at various locations in the Pacific Ocean (e.g., Stanhill and Cohen, 2008), or at other warm-pool regions (e.g., Pavlakis et al., 2008), as a driving force for the fast-coupled air-sea responses that are coherent over broad spatial extent (Meehl et al., 2008; van Loon and Meehl, 2008). Finally, an important practical concept of the "modulated annual cycle," which accounts for the intrinsic nonlinearity of the weather-climate forcings and feedbacks, has been recently developed by Wu et al. (2008).

Both d'Orgeville and Peltier (2007) and Zhang and Delworth (2007) showed the intimate multiscale coupled interactions and connections among dominant timescales and patterns of climate variability involving the Pacific Decadal Oscillation (PDO), the related North Pacific Multidecadal Oscillation (NPMO), and the Atlantic Multidecadal Oscillation (AMO). Although d'Orgeville and Peltier (2007) did not commit to any particular mode as the leading variable, Zhang and Delworth (2007) suggested a lagged North Pacific response to the AMO forcing of about 13 years that is connected through a chain of dynamical atmospheric teleconnections (induced first from AMO-related northward oceanic heat transport) and then amplified by the positive local air-sea feedback over the central and western North Pacific. Zhang and Delworth (2007) further deduced that a regime shift of the North Pacific opposite to the 1976-1977 shift might be expected soon, following the switch of the AMO to a positive phase around 1995.

Three inter-related causes support a strong control of natural multidecadal-tocentennial scales of climate variation through a solar-Arctic connection mechanism: 
Cause A: A persistent and systematic variation of the solar TSI and related insolation gradient modulates the atmospheric heat transport from the tropics to the Arctic, and hence modulates the Arctic temperature change itself with little or no delay.

Cause B: Thermal perturbations lead to both natural modulation of the Arctic sea ice and transport of fresh water through the Bering Strait, and from the Arctic through both the Greenland Sea and Denmark Strait and the Canadian Arctic Archipelago pathways to deep water formation sites spread across the North Atlantic from the Greenland-IcelandicNorwegian (GIN) Seas to the east and at the Labrador Sea in the west.

Cause C: Further effects are: (1) thermal, freshwater, and salinity perturbation of the Atlantic MOC-THC; (2) the delayed connection of about 5 to 20 years with the tropical Atlantic SST and the InterTropical Convergence Zone (ITCZ); and (3) coupling of the affected tropical Atlantic processes feeding back to the MOC-THC.

It is important to note that current climate models are not yet able to account for all the empirical and proxy evidence and relations noted here (e.g., Zhang and Delworth, 2007; Alexander, 2009). Kravtsov and Spannagle (2008), for example, make use of the fact that the AMO signals contained in the difference (suggesting that climate models have failed to account for the AMO) between the observed SST and the multimodel ensemble-mean SST from the CMIP3 (Coupled Model Intercomparison Project Phase 3) database, suggesting that AMO is a natural climatic signal plausibly related to the oceanic thermohaline circulation (THC). Davis and Brewer (2009) pointed out that climate models may overemphasize the seasonal response to insolation changes when compared to the differential latitudinal response which, in turn, translates into an incorrect representation of the latitudinal temperature gradient that is fundamental for capturing climate dynamics (Lindzen, 1994; Jain et al., 1999). Such a zero-order climate modeling barrier has been recently reframed by Rind (2008, p. 855) as "the consequences of not knowing lowand high-latitude climate sensitivity."

Finally, two further assumptions regarding the multidecadal- to centennial-scale solar-Arctic connection mechanism. First, the solar-Arctic mechanism borrows from recent studies by van Loon and Meehl (2008) and Meehl et al. (2008), which focus on coupled surface responses in the Pacific region to the Sun's decadal peaks, giving rise to their hypothesized solar-induced, hydrology-amplified climatic responses. Multidecadal to centennial responses could represent the envelope of the responses to the solar decadal peaks. However, the mechanism proposed here specifies responses in the Arctic and Atlantic basins and postulates equivalent and related responses elsewhere. Second, the solar-Arctic mechanism assumes the importance of a significant coupled thermal-salinity-cryospheric interaction involving the Arctic and many other climatic COAs around the world. Behl and Kennett (1996) discussed the connections of anoxic events in the Santa Barbara basin with the Dansgaard-Oeschger warm interstadials recorded in the GISP2 core 
for the past $60 \mathrm{kyr}$, and Wang et al. (2008) discussed the strong coupling between the East Asian Summer Monsoon system and the North Atlantic, especially during the cold glacial interval between 75 to $10 \mathrm{kyr}$ BP. However, different regions may not be so optimally teleconnected at a much warmer interglacial time when there is little Arctic or Northern Hemisphere volume of ice, such as during the MIS stage $5 d$ (Zhou et al., 2008). ${ }^{2}$

This paper offers support for the proposed solar-Arctic mechanism for climate variations on multidecadal to centennial timescales. The mechanism can also be compared and contrasted with two other promising Sun-climate connection scenarios via the decadal solar UV and TSI mechanisms reviewed below.

\section{THE DECADAL SOLAR UV AND TSI MECHANISMS}

Kodera (2004) showed a dynamical response of the Indian summer (i.e., JulyAugust) monsoon that perhaps can be traced to the downward-propagating effects of wave-mean flow interactions through the forcing by relatively stronger solar decadal UV radiation in the mesosphere and stratosphere. Kodera and Shibata (2006), using a unique and powerful new diagnostic technique, showed how enhanced solar heating in the tropical lower stratosphere, while suppressing convective activity in the equatorial region, enhances convective activity in off-equatorial regions and ultimately produces a change in the meridional circulation in the tropical troposphere. The analyses by Claud et al. (2008) show added spatial complexity to this dynamical coupling of the Indian summer monsoon system to the 11-year solar activity cycle. Such a proposed top-down response to solar decadal UV forcing on the Indian summer monsoon offers a remote teleconnection to both the climatic variations and trends in the Pacific equatorial cold tongue region and the North Atlantic (Selten et al., 2004; Compo and Sardeshmukh, 2008) through what is known as the circumglobal wave teleconnection mechanism (e.g., Branstator, 2002; Watanabe, 2004; Ding and Wang, 2005).

Van Loon and Meehl (2008) and Meehl et al. (2008), through the powerful combination of data analyses and climate modeling experiments, showed how the fast and closely coupled surface responses to changing solar surface radiation between solar activity maxima and minima could add to the top-down responses through the solar UV mechanism proposed by Kodera and colleagues. Specifically, van Loon and Meehl (2008) showed that the coupled surface responses in the Pacific to TSI variation is such that in solar peak forcing years, the sea level air pressure (SLP) is above normal in the Gulf of Alaska and south of the equator, which in turn produces stronger southeast trade winds across the equatorial Pacific and causes increased upwelling and hence cooling SST tendencies broadly across the Pacific Ocean. Using two GCMs at NCAR, Meehl et al. (2008) sketched a coupled response to peaks of solar decadal TSI forcing that involves increased latent heat flux and evaporation, which in turn is carried to the Pacific Intertropical convergence zone (ITCZ) and South Pacific convergence zone (SPCZ) to intensify both precipitation regimes. The resulting solar response patterns resemble La Niña-like events, but yet are distinct from them, mainly by virtue of their different vertical profile of responses, especially in the stratosphere (van Loon and Meehl, 2008). 
Modeling experiments conducted by Emile-Geay et al. (2007) suggest that the powerful ENSO coupled air-sea interaction system can serve as a mediator ${ }^{3}$ of the persistent solar TSI forcing on climate over the Holocene. Their sensitivity calculations, with the intrinsic solar TSI variation ranging from $0.05 \%$ to $0.2 \%$ to $0.5 \%$ over the Holocene, coupled with the orbital forcing effect, generated El Nino-like SST anomalies at times of decreased TSI, which is consistent with the empirical results by van Loon and Meehl (2008).

In summary, Kodera and colleagues proposed a top-down forcing-response scenario for a Sun-climate decadal connection that more directly involves the decadal solar UV forcing, while van Loon, Meehl and colleagues sketched a bottom-up forcing-response scenario for their Sun-climate connection on decadal timescale, which invokes decadal solar TSI forcing.

The strength of the bottom-up scenario of coupled surface air-sea responses to a persistent solar TSI forcing by van Loon, Meehl, and colleagues is that it offers a better explanation for why the multidecadal- to centennial-scale variability can be found in such a diverse range of climate-proxy archives from the bottom of the sea to high mountain tops (Table A1, Appendix). In contrast, it is harder to conceive of a spatially coherent and temporally persistent near-surface response over long distances, wide geographical conditions, and different topographic settings if the initial meteorological and climatic impact centers are rooted in the tropical mesosphere and stratosphere as a response to the decadal solar UV forcing.

Although the decadal signal for solar irradiance forcing of global-averaged surface temperature has recently been confirmed by Tung and Camp (2008), the actual scenario for a physical connection has not been identified. Lim et al. (2006) found that solar irradiance modulation of local and regional relative humidity, in combination with the related climatic distribution of clouds and water vapor over the tropical Atlantic, is sufficient to explain the observed tropical Atlantic decadal oscillation.

\section{RESULTS AND DISCUSSION}

Empirical Evidence and Mechanistic Explanation for Interrelated Causes and Responses $A, B$, and $C$

Soon (2005) showed evidence of natural climate variations on multidecadal to centennial timescales through a solar-Arctic connection mechanism. Figure A1 (Appendix) updates the previously published solar TSI-Arctic surface air temperature correlation in Soon (2005). ${ }^{4}$ The results presented by Kauker et al. (2008) strongly support the multidecadal variations of the Arctic surface temperature from the Arctic Atlantic, to the Arctic Pacific and then to the Arctic Greenland/Iceland sectors (the chart is available upon request). Figure 1 shows that the solar TSIArctic-wide temperature correlation can also be found on a much smaller regional scale, as demonstrated by similar TSI-temperature correlations for two coastal stations of southern Greenland: Godthab Nuuk in the west and Ammassalik to the east. It is important to note that available oceanographic data at Fyla Bank off Godthab Nuuk show that the early $20^{\text {th }}$ century surface thermometer warming was 

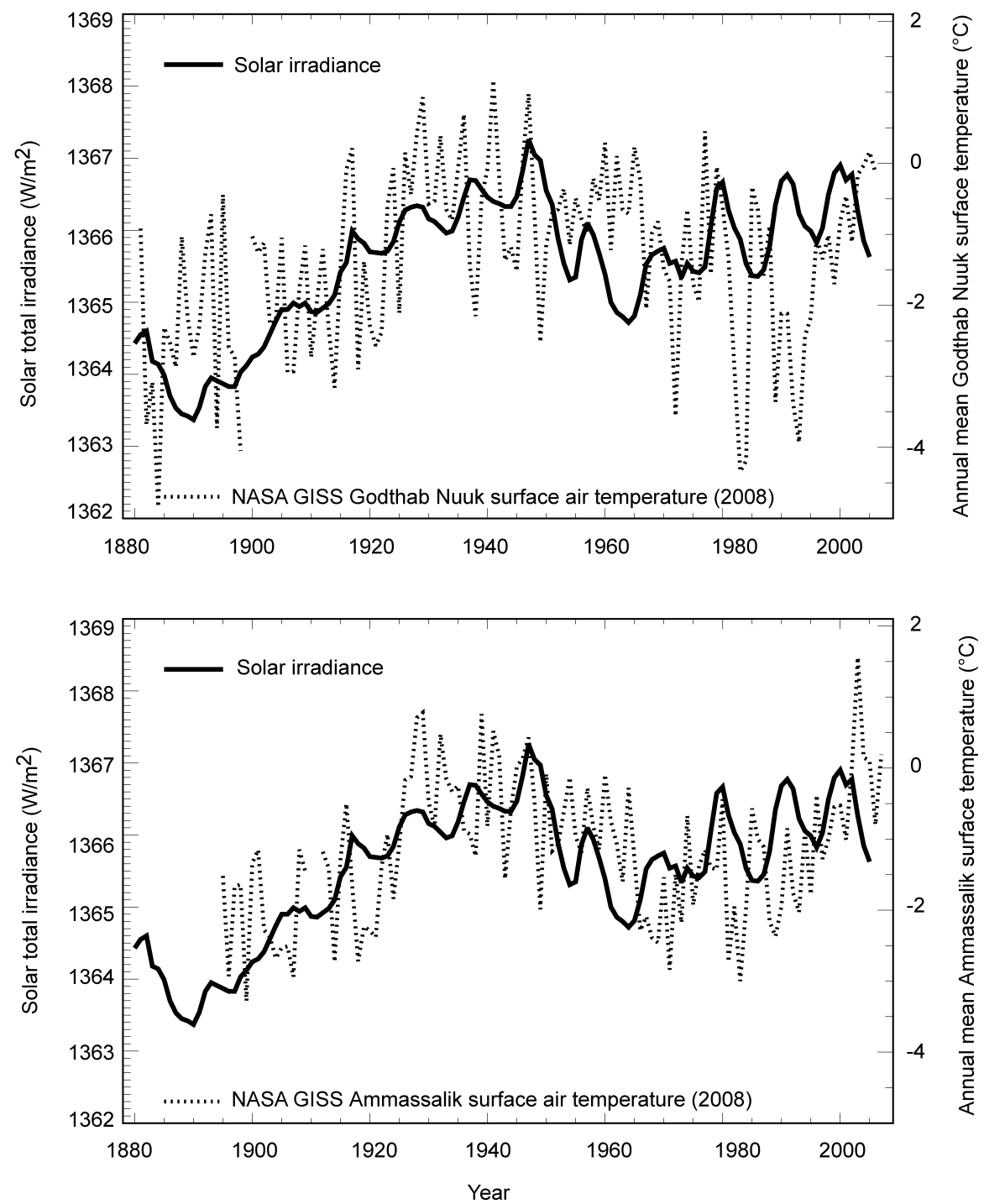

Fig. 1. The annual mean estimates of total solar irradiance (solid line) compared with the surface temperature records from two coastal Greenland stations: Godthab Nuuk (dotted curve; top panel) and Ammassalik (dotted curve; bottom panel) from about 1881 to 2007 (from "after homogeneity adjustment" records in http://data.giss.nasa.gov/gistemp/station_data/). This result adds regional details to the TSI-Arctic-wide surface temperature correlation identified in Soon (2005).

detected around 1920 at the surface ocean (Holland et al., 2008). Such a consistent pattern of correlations on different spatial domains and scales is an important ingredient for a physical solar-Arctic connection.

Another important update and extension is the new result by Jiang et al. (2005) showing the consistent role for solar irradiance forcing in triggering and 
maintaining the multidecadal to centennial variation of the SSTs around the North Icelandic Shelf over the last 2000 years. Jiang et al. (2005) further noted the relatively stronger temperature responses during winters than summers, which is consistent with the result outlined in Soon (2005). High-resolution proxy annual-mean and wintertime SSTs from a coral record at Bermuda (Goodkin et al., 2008a, 2008b) showed enhanced multidecadal-scale variability during the late $20^{\text {th }}$ century when compared to variability near the end of the Little Ice Age. These results, together with the evidence on the sensitivity of Arctic Ocean ice cover and thickness to atmospheric poleward energy flux by Soderkvist and Bjork (2004) in their coupled ocean-ice-atmosphere column model, support the proposed solar-Arctic connection Cause A. The enhanced poleward atmospheric transport scenario is supported by the consistent increases in wind stress trends over the Arctic basin shown for annual mean, winter, and summer values for 1948-2006 (Hakkinen et al., 2008). Indirect evidence for variable poleward heat transport for earlier periods (i.e., before 1950) can be found in the multidecadal variation of the equator-to-pole (EPG) surface temperature gradient as well as the multidecadal-scale modulation of the phase of the EPG annual cycles (Jain et al., 1999).

Graversen et al. (2008), in their close examination of the vertical pattern of recent Arctic warming, concluded that much of the observed Arctic warming aloft is related to changes in poleward atmospheric heat and moisture transports rather than from near-surface snow and ice albedo feedbacks, as has been modeled and suggested in climate model experiments with increased atmospheric $\mathrm{CO}_{2}$. This result is consistent with the theoretical and modeling studies by Alexeev et al. (2005), Winton (2006), and Cai and Lu (2007), where poleward heat transports, plausibly linked to differential latitudinal response to insolation changes, are shown and argued to be more important in explaining polar warming than direct surface snow and ice albedo feedbacks. Smedsrud et al. (2008) showed that indeed the poleward atmospheric energy flux to the Arctic has increased overall for the last 50 years, from 1956 to 2006, which is consistent with solar-Arctic connection Cause A, but they emphasized that the tendency for a net increase over more recent decades has slowed. L'Heureux et al. (2008), Overland et al. (2008), Serreze et al. (2008), Zhang et al. (2008), and Lindsay et al. (2009) all provided updated data series up to 2007 and discussion of the key role played by the recent shift in spatial patterns of atmospheric forcing and the strengthened poleward atmospheric heat transport directly or indirectly reaching the central Arctic. Polyakov et al. (2005) showed evidence for the enhanced North Atlantic warm water intrusion into the Arctic Ocean and Barents Sea, while Shimada et al. (2006) documented the influx of warm Pacific summer waters into the Arctic Ocean via the Bering Strait in order to account for the observed rapid changes in the Arctic climate system. Serreze et al. (2008) argued that the near surface-based Arctic amplification signal through snow and ice albedo feedbacks may soon be emerging if the Arctic Sea continues to lose its ice, and emphasized that their results are not in conflict with those of Graversen et al. (2008).

Finally, direct hydrographic data from the northeast North Atlantic and Nordic Seas in Holliday et al. (2008) showed not only the reversal of the 1960 to 1990 s freshening trend but also seem to offer practical short-term forecasts for temperature 
and salinity around the Fram Strait region for Atlantic inflow conditions to the Arctic Ocean. A similar forecast based on short-term hydrographic tendencies for Labrador Sea regions has also been proffered by Yashayaev (2007) and Yashayaev et al. (2007), but Yashayaev and Loder (2009) recently reported a sudden atmospheric cooling and enhanced production of Labrador Sea water in the fall-winter 20072008 season, which disrupted the steady warming around the region since 1994 . Similarly, Vage et al. (2009) documented a surprising return of winter deep convection to the subpolar gyre in both the Labrador and Irminger Seas, apparently without going through a phase of preconditioning. This most up-to-date situation in the Labrador Sea should points to the need for caution when attempting to forecast any near- or long-term changes in the northern North Atlantic and Arctic. ${ }^{5}$

Empirical evidence supporting the solar-Arctic connection Cause B may be found in the important synthesis of observational data in Polyakov et al. (2008), demonstrating the multidecadal variability of climate variables in the Arctic and their interconnections, which include the Arctic surface air temperature, upper 150-m Arctic Ocean freshwater content, fast ice thickness, intermediate Atlantic water core temperature of the Arctic Ocean, and upper 300 m North Atlantic water salinity. Here, one might interpret that a warmer Arctic (detected in both air and ocean-water temperatures) led to above-normal melting of Arctic sea ice and excess flushing of Arctic freshwater to the Nordic seas and the subpolar North Atlantic basins. The observational data of Polyakov et al. (2008) are consistent especially with the newly reconstructed freshwater content data series over the northern Atlantic by Pardaens et al. (2008).

Dima and Lohmann (2007) independently sketched a dynamically consistent framework for the $\mathrm{AMO}$, and were able to fill in some important feedbacks and delay factors. They show the hemispheric wavenumber- 1 sea level air pressure pattern to be related to the Fram Strait sea ice export, which, in turn, affects the THC/ MOC oceanic circulation and hence the sea surface conditions in both the North Atlantic and North Pacific. Dima and Lohmann (2007) spelled out the role of the THC adjustment to freshwater forcing, the Atlantic SST response to MOC, and the oceanic adjustment in the North Pacific as key delays in the chain, while the oceanatmosphere-sea ice interactions in the Atlantic, Pacific, and Arctic oceans served as the crucial negative feedbacks to sustain the AMO oscillation on timescales of about 70 years. Jungclaus et al. (2005) also proposed a scenario of Arctic-North Atlantic interactions with the multidecadal variability of Atlantic MOC/THC based on the outputs of their 500-year GCM control, unforced, run. The important extension of climate modeling experiments by Grosfeld et al. (2008) shows that, in addition to attributing the origin of the 60-70 year scale oscillation to the Atlantic Ocean, there is possibly a separate and distinct scale of about 80-100 years that is intrinsic to the Pacific Ocean.

The paper's argument for a multidecadal- to centennial-scale variability adopts and accepts most of the detailed physical processes outlined in Dima and Lohmann (2007), but the solar-Arctic connection picture given here also includes a more direct emphasis on climatic modulation by the Arctic (i.e., the call for direct involvement of Arctic-wide surface temperature and sea ice and fresh water in the Arctic basin, with emphasis on pathways for freshwater exchanges and transports, 
rather than merely sea ice export from the Fram Strait); and a wider range of spatialtemporal scales beyond the more limited 70- to 80-year variability set in the Dima and Lohmann (2007) framework, because the memory and turning points for the multiscale oscillation in this solar-Arctic connection picture appear to be decided more by the external TSI forcing. For this reason, the phrase "multidecadal to centennial timescales ${ }^{\prime \prime}$ is used throughout this paper.

Adding to these processes is the current emphasis on the effects of influx of lowsalinity Pacific water through the Bering Strait (Aagaard et al., 2006; Shimada et al., 2006; Keigwin and Cook, 2007) in perturbing the ice and freshwater environment over the Arctic Ocean. These effects are non-negligible and may at times have played a more prominent role than at present (e.g., Wadley and Bigg, 2002; Yang, 2005, 2006; Dickson et al., 2007). Finally, Peterson et al. (2006) and Serreze et al. (2006) confirmed the roles of net precipitation, river discharge, and sea ice attrition as important freshwater sources, compared to the relatively minor contributions of glacial melt. The modeling study by $\mathrm{Wu}$ and Wood (2008) suggests that the recent freshening trend over the subpolar North Atlantic can be explained by a redistribution of freshwater within the Arctic and subpolar North Atlantic and that the redistribution was probably carried out by a perturbed ocean circulation in the subpolar seas and triggered by deep convection in the Labrador Sea.

Both the Arctic sea ice extent data derived by Zakharov (in Johannessen et al., 2004) and the Icelandic sea ice extent (Zhang and Vallis, 2006) provide evidence in support of the inverse relation between Arctic temperature and sea ice extent for about the past 100 years, as proposed in Cause B of this solar-Arctic connection. Quantitative reconstruction by Kauker et al. (2008) also support a significant ice loss over the Arctic basin from 1916 to 1955, although they suggested that the ice loss of this period was somewhat less extensive than the recent loss from mid-1960s to mid-1990s.

In the context of the proposed solar Arctic-mediated climate variation mechanism, it is assumed that the sea ice export is not exactly the same as freshwater export from the Arctic and that more sea ice export from the Arctic basin may be more related to colder conditions within the Arctic, not unlike the notable icerafting events and episodes seen throughout the Quaternary (e.g., Bond et al., 1997, 1999; Vidal et al., 1997; Darby and Zimmerman, 2008; Hill et al., 2008; or counter-views and interpretations by Andrews et al., 2006), or in the summer of 1695 recently re-interpreted by Gil et al. (2006), as well as the great salinity anomaly events of the 1970s, 1980s, and 1990s, modeled and discussed in Zhang and Vallis (2006). But importantly, it is recognized that extra exports of sea ice, episodic or otherwise, or a more continuous nature of the freshening and flushing of water from the Arctic basin to the northern North Atlantic basins (e.g., Condron et al. 2009) would serve as key negative feedbacks for the MOC/THC oscillation. Dickson et al. (2007) highlighted the potentially greater importance of combined ice and freshwater outflows from the Arctic Ocean basin through the Canadian Arctic Archipelago/Nares Strait/Baffin Bay/Davis Strait pathways under a warm Arctic and low-ice-volume climatic regime. ${ }^{7}$ Detailed computer modeling (Proshutinsky et al., 2002; Moon and Johnson, 2005; Dukhovskoy et al., 2006; Condron et al., 2009) shows how the oscillations between the anticyclonic and cyclonic 


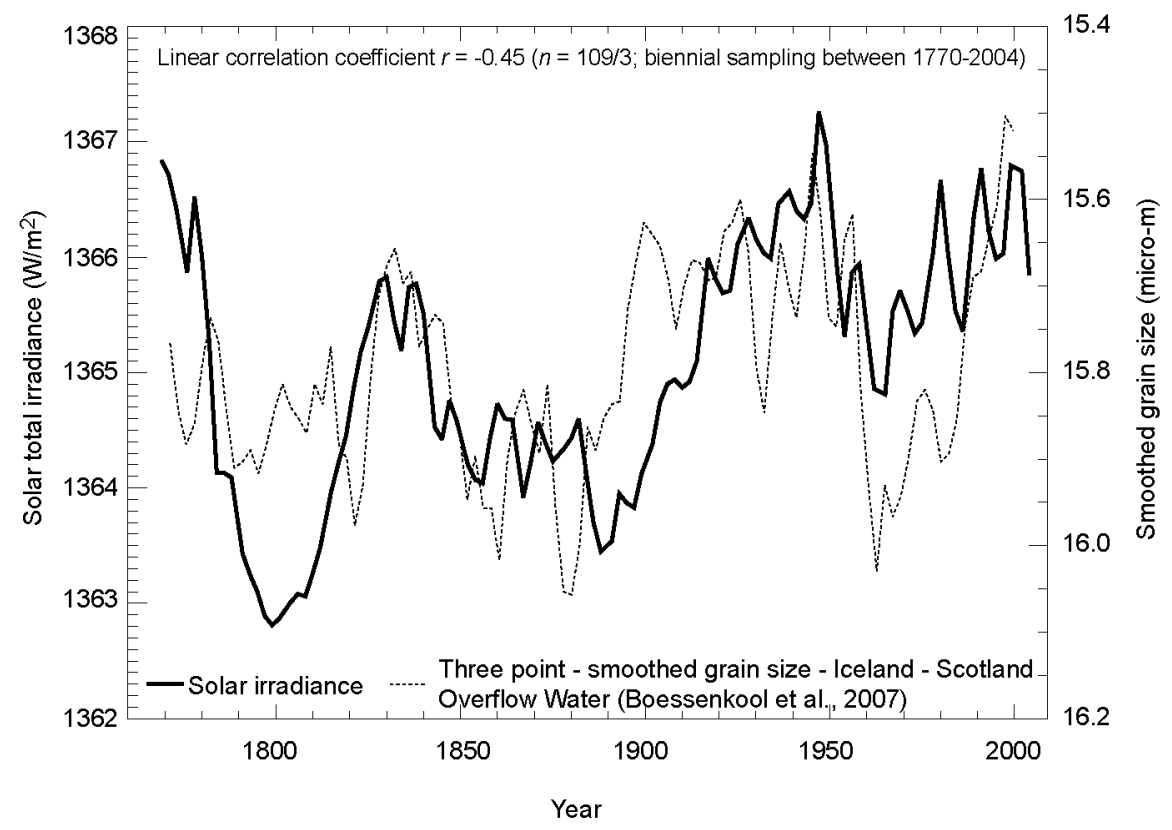

Fig. 2. The annual mean estimates of total solar irradiance (solid line) correlated with the three-point smoothed mean grain-size index (dotted line) of Boessenkool et al. (2007) from about 1770 to 2004. The grain-size index is a proxy for the flow speed of the near-bottom Iceland-Scotland Overflow Water (ISOW) which is, in turn, related to the deep water formation in the Labrador Sea to the west. Smaller mean grain size suggests slower ISOW, and larger grain size implies faster ISOW.

circulation regimes, involving contraction and expansion of the Beaufort Gyre, are affecting how Arctic sea ice and freshwater are stored and released to the northern North Atlantic Ocean.

Figure 2 records plausible evidence for a connection between TSI solar forcing in producing the thermal-freshwater-salinity-related effects on deep-ocean flow of the northern North Atlantic for the full 1770-2004 A.D. interval. It uses new mean grain-size data from Boessenkool et al. (2007) that represents the near-bottom flow speed of Iceland-Scotland Overflow Water (ISOW). It should be further noted that Bossenkool et al. (2007) suggest that the vigor of ISOW is controlled by the transport and characteristics of the Labrador Sea water farther to the west (Jungclaus et al., 2005). The correlation between TSI and the three-point smoothed grain-size index shown in Figure 2 has a correlation coefficient of $r=-0.45$, which even with the reduced degrees of statistical freedom would still constitute a significant correlation. In comparison, Boessenkool et al. (2007) showed a correlation between the grain size with a seven-year smoothed NAO index for the selected (rather than the full data shown in Fig. 2) interval of 1885-2004 with an $r$ value of only $-0.42(n=$ 55). Although it is not the intent of this paper to explain the correlation, but merely to demonstrate plausibility, the apparent correlation in Figure 2 suggests a slower ISOW flow speed with increasing TSI. Finally, the solar-Arctic connection in Cause 


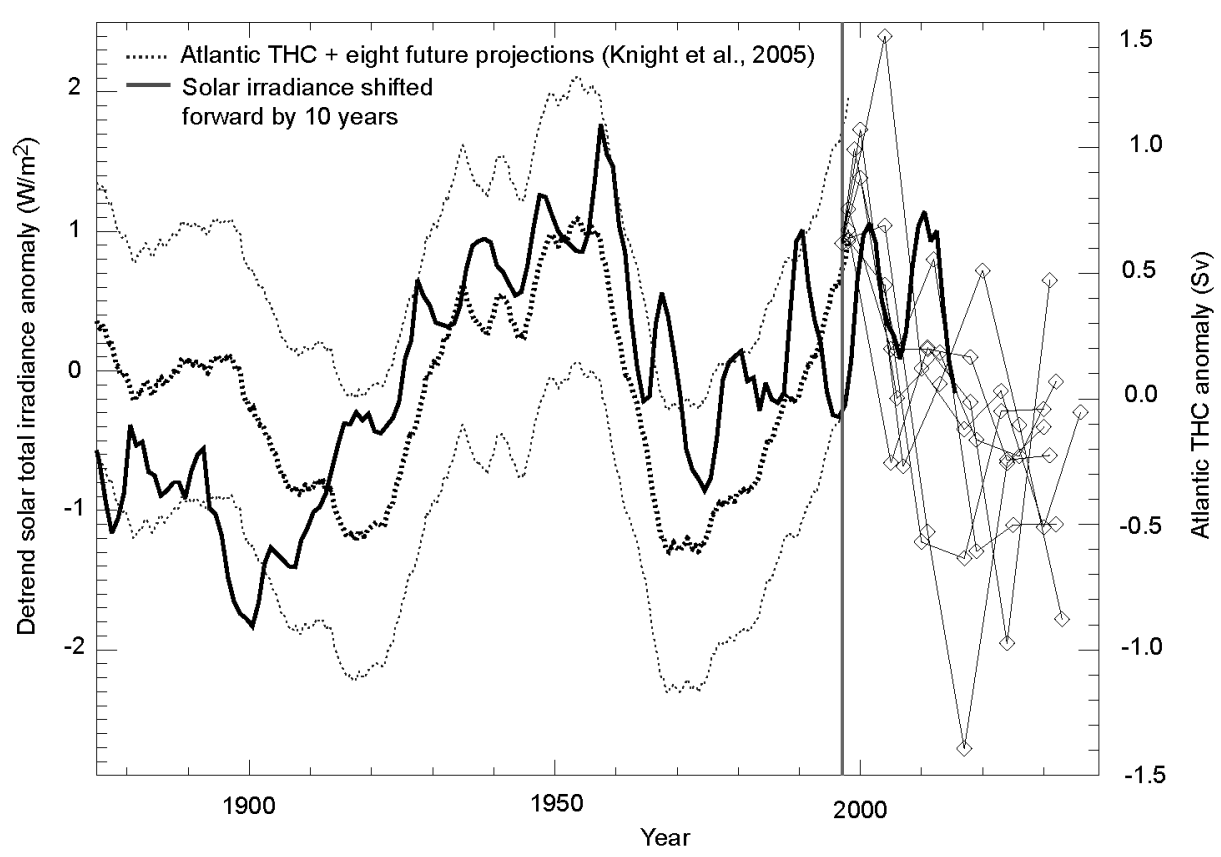

Fig. 3. The detrended total solar irradiance anomaly series shifted forward by 10 years (thick solid line; see also the same shift in Fig. 4) to show correlation with the maximum of the zonal mean of the Atlantic Meridional Overturning Circulation at $30^{\circ} \mathrm{N}$ deduced by Knight et al. (2005) (dotted grey lines with the upper and lower bounds as the "uncertainty" limits). Grey diamond symbols connected with thin solid lines are the eight-member forecasts for the 35 years offered by Knight et al. (2005). A detrended solar TSI series was used in order to compare more fairly with the normalized measures of SST and THC anomalies used in Knight et al. (2005). See Kravtsov and Spannagle (2008) for a discussion of the details of the detrending of datasets for the construction of AMO-related SST changes, and Vellinga and $\mathrm{Wu}(2004)$ for a discussion of why the maximum MOC index is a useful proxy for the Atlantic THC for the study of AMO, but the index is clearly not useful for assessing interannual THC variability.

B outlined here may also find support from the specific documentation of the 75- to 80 -year period from the Holocene history of drift ice within the northern North Atlantic region by Moros et al. (2006).

In the search of a physical mechanism and understanding of a Sun-climate connection, one need not be automatically hunting for maximum possible statistical correlations between any two variables (e.g., Soon et al., 2000). For example, Zhang et al. (2007) showed how an equally good fit of the observed detrended Northern Hemispheric temperature time series can be achieved with relatively high correlations, and yet each of the good fits was obtained under dramatically different heat flux redistribution and transport scenarios. Such a reality suggests that high correlations between variables do not imply correct identification of a physical mechanism given that multiple physical processes could well be responsible for establishing a quasi-mean state or any deviation from the mean.

Figures 3 and 4 show the empirical support for the proposed solar-Arctic connection Cause C. In Figure 3, the maximum MOC index (i.e., centered around $30-35^{\circ} \mathrm{N}$ 

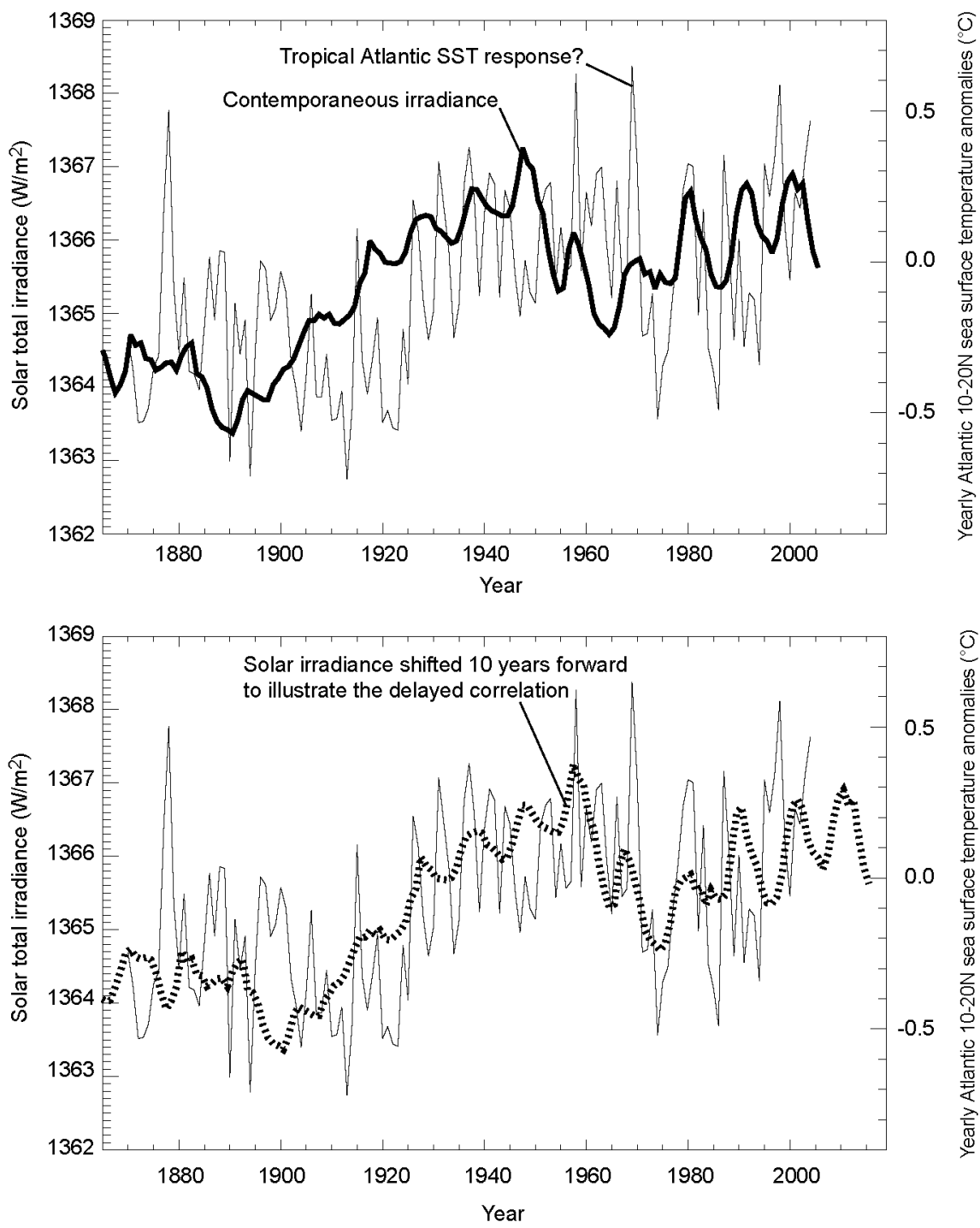

Fig. 4. The annual-mean estimates of total solar irradiance (TSI) versus the tropical Atlantic SST at $10-20^{\circ} \mathrm{N}$ from 1870 to 2004 (top panel), and with the solar TSI advanced forward by 10 years (bottom panel) in order to illustrate the delayed connection of the tropical Atlantic SST to solar TSI forcing effects initiated first within the Arctic and North Atlantic basins.

roughly 1000 to $2000 \mathrm{~m}$ below surface) as deduced from the SST distribution by Knight et al. (2005) is plotted with the TSI series shifted forward by 10 years, corresponding to the estimated delayed response in lower latitudes. Figure 4 shows a similar comparison with tropical Atlantic SST at around $10-20^{\circ} \mathrm{N}$. The chosen delay time of 10 years is only a rough estimate for the thermal-cryospheric-salinity and mechanical wind stress effects occurring within the Arctic and northern North 
Atlantic basins to propagate southward. But it is clear from both empirical evidence (Curry et al., 1998; Molinari et al., 1998) and careful ocean modeling (Yang, 1999) that a physical delay of some 5 to 20 years is reasonable. Yang (1999), for example, pointed out a five-year delay for decadal variations in the Labrador Sea and the tropical Atlantic dipole index set by coastally trapped waves, rather than the probably longer advection time through the Deep Western Boundary Current (Goodman, 2001). In the AMO framework of Dima and Lohmann (2007), a delay of 10-15 years was deduced for the time it will take for the freshwater forcing on both the North East Atlantic deep water and Labrador Sea deep water convection sites to affect the MOC circulation. Jungclaus et al. (2005) deduced an optimal lead time of 12 years for changes in the convection intensity in the Labrador Sea to affect the MOC/THC. Finally, Latif et al. (2006) offered evidence and argument for the atmospheric NAO index to lead the Atlantic Dipole Index ${ }^{8}$ by 5 to 20 years, where this index is proposed as a good proxy for THC/MOC circulation. Based on inland temperature proxy data, the finding by Eichler et al. (2009) of 10- to 30-year delays between the solar forcing proxy and Siberian Altai Mountain region temperature throughout the 1250-2000 AD period is consistent with the proposed solar-Arctic and Atlantic MOC-mediated mechanism.

Additional Mechanistic Explanation for Interrelated Causes and Responses $A, B$, and $C$

The wind-driven subtropical and subpolar gyre circulations both across the Pacific and Atlantic Oceans may be also important for the plausible solar-induced feedbacks and delays to help sustain the multidecadal to centennial variations (e.g., Wu et al., 2003; Zhang and Vallis, 2006; Hasegawa et al., 2007; Qiu et al., 2007; DiLorenzo et al., 2008; Guan and Huang, 2008; Alexander, 2009; Saenko, 2009). The modeling study by Wu et al. (2003), for example, shows that in the North Pacific, the multidecadal memory may be rooted in the slow adjustment of the subtropical/subpolar gyre in response to wind stress imposed in the central North Pacific and the slow growth/decay of the SST anomalies that propagate eastward in the Kuroshio Extension region. Saenko (2009) showed the important climatic impacts of wind stress, especially those around regions poleward of $30^{\circ}$, with oceanic heat transport accounting for only a small fraction of total poleward energy transport, and where, if one were to remove that wind stress forcing, surface temperatures at high-latitude regions could drop by more than $10^{\circ} \mathrm{C}$ with the mean position of the simulated sea ice edge moving equatorward and reaching latitude $40^{\circ} \mathrm{N}$. The important study by Guan and Huang (2008), which emphasizes mechanical energy in order to sustain the THC, shows how adding the wind-driven gyre not only leads to a more complete modeling of the physical processes related to THC, but also changes the threshold value of the THC dynamical bifurcation property greatly. Therefore, both fresh water and wind forcing will be key elements for the current solar- Arctic connection picture.

It may not be straightforward to explain the seemingly counterintuitive relationship of stronger Atlantic maximum MOC with increased TSI forcing indicated in Figure 3. But the plausibility of a decreased equator-to-pole surface density (i.e., 
from an enhanced thermal and fresh water perturbation and modulation of the convective sinking regions for deep water formation spread across the North Atlantic with increased TSI forcing) leading to stronger, rather than weaker, thermohaline circulation was studied by Nilsson and Walin (2001) and Nilsson et al. (2003). The theory of Nilsson, Walin and colleagues viewed the slow upwelling of dense water overall in the low latitudes and the Southern Ocean (see also Visbeck, 2007; Toggweiler and Russell, 2008), rather than high-latitude production and sinking of dense water as the rate-limiting branch of THC. ${ }^{9}$ The Nilsson et al. theory showed, with a reasonable model of interval wave mixing, that the vertical diffusivity would increase with decreasing surface equator-to-pole density contrast, and that would deepen the thermocline and, in turn, lead to a stronger THC.

The proposed Cause $\mathrm{C}$ mechanism must necessarily include coupling with the multidecadal- to centennial-scale variations of the Atlantic Intertropical Convergence Zone, as noted in several proxy archives (Nyberg et al., 2001; Poore et al., 2004; Peterson and Haug, 2006; Black et al., 2007) and in climate modeling experiments (Vellinga and Wu, 2004; Chiang and Bitz, 2005; Zhang and Delworth, 2005). In general, these studies have highlighted a robust shift of the ITCZ southward during North Atlantic cooling and slower MOC/THC and a northward ITCZ shift during the opposite phase of stronger MOC/THC and warmer North AtlanticArctic conditions. The most important aspect of these studies that focused on the tropical Atlantic is the related feedbacks to the MOC/THC itself. Vellinga and $\mathrm{Wu}$ (2004) placed a greater emphasis on the role of low-latitude fresh water through the ITCZ variability on a centennial timescale for feeding back to the THC circulation. This emphasis may also be ultimately related to the THC variability theory of Nilsson and Walin (2001) and Nilsson et al. (2003). There is little doubt that both the ITCZ and inter-hemispheric SST gradient proposed by Vellinga and Wu (2004) are dominant weather-climate processes operating on seasonal and interannual timescales that can feed back and couple to the solar TSI-induced Arctic-high latitude processes emphasized in this paper. But it is harder to find justification in available data that "sustained salinity anomalies slowly propagate toward the subpolar North Atlantic at a lag of 5-6 decades" to maintain the centennial-scale variability of Atlantic THC, as seen in model outputs by Vellinga and Wu (2004, p. 4498).

\section{More Related Consequences and Impacts}

Several important and related consequences and connections of multidecadalto centennial-scale variations of the Atlantic MOC/THC have recently been pointed out by Dong et al. (2006), Goswami et al. (2006), Knight et al. (2006), Lu et al. (2006), Li and Bates (2007), Sutton and Hodson (2007), Timmermann et al. (2007), Chang et al. (2008), Denton and Broecker (2008), Feng and Hu (2008), Li et al. (2008), Ting et al. (2008), and Wang et al. (2009).

In Figure 11 of their study of the effects of a weakening Atlantic MOC/THC on the coupled ENSO system, Timmermann et al. (2007) made the remarkable observation that, during the positive phase of AMO, the annual cycles of the Nino-3 SST are intensified, while the ENSO-scale (i.e., 2 to 8 years) SST variability is relatively more muted, and the inverse occurs for the opposite phase of AMO. Such a 
nonlinear multidecadal modulation of the annual-cycle and ENSO signals, which was clearly noted by White and Liu (2008b), may ultimately be consistent with the new insight they offered concerning the non-linear alignment of El Niño/La Niña episodes with the combined signals from the 11-year solar cycle-generated $3^{\text {rd }}$ (3.6year) and $5^{\text {th }}$ (2.2-year) harmonics. On millennial timescales, proxy data (Stott et al., 2002) from the western Pacific warm pool region suggest that El Niño conditions correlate with cooler-stadial conditions around Greenland and the North Atlantic, while La Niña conditions tend to correlate with warmer interstadials.

Denton and Broecker (2008) demonstrated the non-obvious connection between $\mathrm{AMO}$ and the retreating and advancing activity of 38 selected glaciers in the Swiss Alps with little or only slight delays in the glacier response. Such a tight coupling between glacier activity in the Swiss Alps and AMO was suggested to arise from the effects of AMO on European summertime temperatures. Chang et al. (2008) showed the active role played by MOC/THC in explaining abrupt climate events in the tropical Atlantic, including the rapid reduction of summer monsoonal wind and rainfall over West Africa. Knight et al. (2006) and Ting et al. (2008) showed the wide-ranging climatic impacts of the $\mathrm{AMO}$, including rainfall over the Sahel and sea surface temperature over the main development region of Atlantic hurricanes (Fig. 4).

Goswami et al. (2006), Lu et al. (2006), Sutton and Hodson (2007), Feng and Hu (2008), and Li et al. (2008) found multidecadal modulation of Indian summer monsoon rainfall through empirical data analyses and modeling experiments. Although the AMO-Indian monsoon rainfall relationship is not fully robust, the general tendency is such that a positive AMO/MOC/THC phase, via both persistent tropospheric and near-surface response pathways, leads to more summer rainfall with modulated delay responses until the months of September and October. Li and Bates (2007) showed atmospheric GCM results that yielded relatively uniform, warmer winters in East China but a dipolar north-south positive-negative pattern of precipitation responses during the positive AMO phase and inversely for the negative AMO phase. Earlier, Tan et al. (2004) showed an interesting correlation between the warm-season temperature proxy for Beijing and the North Atlantic Drift ice index of Bond et al. (2001) covering the last 2650 years, but they did not offered a working mechanism. Wang et al. (2009) emphasized the influences of $\mathrm{AMO}$ on Asian monsoonal climate in all four seasons, producing weakened winter monsoons but enhanced summer monsoons related to AMO-modulated tropospheric heating anomalies.

Finally, the works by Braun et al. (2005), Weng (2005), and Dima and Lohmann (2009) support the present proposal by showing how the various key intrinsic timescales and physics related to this solar-Arctic connection can interact and connect dynamically from annual cycles to the noted millennial-scale oscillation of about 1470 years of the Dansgaard-Oeschger events noted during glacial intervals. ${ }^{10}$ Weng (2005), using both ocean temperature data and a toy model, illustrated how in a nonlinear weather-climate regime that even a "small" change in TSI forcing will effectively interact with and couple to the seasonal forcing to generate and sustain climate responses and variations of multidecadal to centennial timescales. ${ }^{11}$ Braun et al. (2005), using the Potsdam Institute's intermediate complexity coupled 
climate system model, showed how the 1470-year glacial climate cycle could be robustly and realistically generated solely from the periodic forcing of freshwater input into the North Atlantic Ocean in cycles of 87 and 210 years, which were identified by the authors as the solar Gleissberg and deVries/Suess activity cycles, respectively. ${ }^{12}$

Dima and Lohmann (2009) suggest that, instead of being the synchronization of the two basic solar cycles or any amplification of a weak direct 1500-year forcing of unknown origin by THC, the origin of the 1500-year cycle is best viewed as the rectification of an external solar forcing through dynamical connection to a threshold internal response of the THC. Their work emphasizes that observed millennial variability in paleo-proxy records should be considered as a derived dynamical mode of the climate system without physical processes on a fixed millennia timescale, regardless of whether this timescale is rooted in the Sun or in Earth climate system. This possibility certainly adds another layer of complexity in the study of the Sun-climate connection.

\section{CONCLUSION}

This paper proposes three interrelated causes for natural climate variations on multidecadal to centennial timescales through a solar-Arctic connection mechanism. The first, Cause A, is that a persistent and systematic variation of the solar TSI and related insolation gradient modulates the atmospheric heat transport from the tropics to the Arctic, and hence modulates the Arctic temperature change itself with little or no delays.

The second, Cause B, is that thermal perturbations lead to both natural modulation of the Arctic sea ice and to transport of fresh water through the Bering Straits and from the Arctic through both the Greenland Sea and Denmark Strait and the Canadian Arctic Archipelago pathways to deep water formation sites spread across the North Atlantic from the Greenland-Icelandic-Norwegian (GIN) Seas to the east and at the Labrador Sea to the west. The third, Cause C, is that further effects are: (1) thermal, freshwater, and salinity perturbation of the Atlantic MOC-THC; (2) the delayed connection of about 5 to 20 years with the tropical Atlantic SST and the InterTropical Convergence Zone (ITCZ); and (3) coupling of the affected tropical Atlantic processes feeding back to the MOC-THC. This three-part solar-Arctic climate variation mechanism emphasizes plausible physical arguments rather than statistical correlations.

The proposed solar-Arctic connection chains from Causes $\mathrm{A}-\mathrm{C}$ have good empirical support, and this mechanism appears to explain the operation of coupled air-ocean-ice responses over broad areas connecting the Arctic and North Atlantic to other locations on multidecadal to centennial timescales. This proposal offers the opportunity for a rejectable scientific hypothesis of a physical Sun-climate connection. The new synthesis should be viewed as a step forward in the long quest to understand how the full weather-climate continuum varies on multidecadal to centennial timescales by highlighting the role of solar irradiance forcing upon the Arctic region, in not only sustaining and amplifying the natural climatic oscillation 
and variation, but also in the selectivity or specification of the broadband nature of the spatial and temporal scales of the climatic responses involved.

Acknowledgments: I thank two referees for their constructive comments and edits that improved the paper. I also thank all colleagues whose works are cited here, and especially those who have allowed access to their hard-earned data series: Nicola Scafetta, Karin Boessenkool, Igor Yashayaev, Igor Polyakov, Mihai Dima, Lars Smedsrud, Jeff Knight, Rob Allan, Daniel Hodson, David Holland, Mads Ribergaard, Frank Kauker, and John Fasullo. I thank Scott Armstrong, Gene Avrett, Sallie Baliunas, Dan Botkin, Bob Carter, Shaun Cheok, Susan Crockford, Bob Ferguson, Dave Fettig, Kesten Green, Joe Kunc, Keith Lockitch, Christopher Monckton, Lubos Motl, Jane Orient, Eric Posmentier, Art Robinson, Mitch Taylor, Bin Wang, and the late Robert Jastrow for their encouragement, and Gene Avrett and Steve Cranmer for their editorial help. I further thank Than, Lien and Julia Pham, Chiew-See Chua, as well as Benjamin and Franklin Soon for motivation. This new synthesis was based on a presentation at the $33^{\text {rd }}$ International Geological Congress held in Oslo, Norway, August 6-14, 2008, as well as by another presentation at the International Symposium on Climate and Weather of the Sun-Earth System held at Jakarta, Indonesia, November 24-26, 2008. The views expressed herein are solely those of the author and are independent of sources providing support.

\section{REFERENCES}

Aagaard, K., Weingartner, T. J., Danielson, S. L., Woodgate, R. A., Johnson, G. C., and Whitledge, T. E. (2006) Some controls on flow and salinity in Bering Strait. Geophysical Research Letters, Vol. 33, doi:10.1029/2006GL026612.

Adkins, J. F., Ingersoll, A. P., and Pasquero, C. (2005) Rapid climate change and conditional instability of the glacial deep ocean from the thermobaric effect and geothermal heating. Quaternary Science Reviews, Vol. 24, 581-594.

Alexander, M. A. (2009) Extratropical air-sea interaction, SST variability and the Pacific Decadal Oscillation (PDO). AGU Geophysical Monograph Series (Climate Dynamics: Why Does Climate Vary?), in press.

Alexeev, V. A., Langen, P. L., and Bates, J. R. (2005) Polar amplification of surface warming on an aquaplanet in "ghost forcing" experiments without sea ice feedbacks. Climate Dynamics, Vol. 24, 655-666.

Alley, R. B. (2007) Wally was right: Predictive ability of the North Atlantic "Conveyor Belt" hypothesis for abrupt climate change. Annual Review of Earth and Planetary Sciences, Vol. 35, 241-272.

Andrews, J. T., Jennings, A. E., Moros, M., Hillaire-Marcel, C., and Eberl, D. (2006) Is there a pervasive Holocene ice-rafted debris (IRD) signal in the northern North Atlantic? The answer appears to be either no, or it depends on the proxy! PACES News, Vol. 14, No. 2, 7-9.

Behl, R. J. and Kennett, J. P. (1996) Brief interstadial events in the Santa Barbara basin NE Pacific, during the past 60 kyr. Nature, Vol. 379, 243-26.

Black, D. E., Abahazi, M. A., Thunell, R. C., Kaplan, A., Tappa, E. J., and Peterson, L. C. (2007) A 8-century tropical Atlantic SST record from the Cariaco Basin: Baseline variability, twentieth-century warming, and Atlantic hurricane frequency. Paleoceanography, Vol. 22, doi:10.1029/2007PA001427.

Boessenkool, K. P., Hall, I. R., Elderfield, H., and Yashayaev, I. (2007) North Atlantic climate and deep-ocean flow speed changes during the last 230 years. Geophysical Research Letters, Vol. 34, doi:10.1029/2007GL030285. 
Bond, G. and 9 co-authors (1997) A pervasive millennial-scale cycle in North Atlantic Holocene and glacial climate. Science, Vol. 278, 1257-1266.

Bond, G. and 9 co-authors (1999) The North Atlantic's 1-2 kyr climate rhythm: Relation to Heinrich events, Dansgaard/Oeschger Cycles and the Little Ice Age. AGU Geophysical Monograph Series (Mechanisms of Global Climate Change at Millennial Time Scales), Vol. 112, 35-58.

Bond, G. and 9 co-authors (2001) Persistent solar influence on North Atlantic climate during the Holocene. Science, Vol. 294, 2130-2135.

Branstator, G. (2002) Circumglobal teleconnections, the Jet Stream waveguide, and the North Atlantic Oscillation. Journal of Climate, Vol. 15, 1893-1910.

Braun, H., Christl, M., Rahmstorf, S., Ganopolski, A., Mangini, A., Kubatzki, C., Roth, K., and Kromer, B. (2005) Possible solar origin of the 1,470-year glacial climate cycle demonstrated in a coupled model. Nature, Vol. 438, 208-211.

Braun, H., Ditlevsen, P., and Chialvo, D. R. (2008) Solar forced DansgaardOeschger events and their phase relation with solar proxies. Geophysical Research Letters, Vol. 35, doi:10.1029/2008GL033414.

Cai, M. and Lu, J. (2007) Dynamical greenhouse-plus feedback and polar warming amplification. Part II: Meridional and vertical asymmetries of the global warming. Climate Dynamics, Vol. 29, 375-391.

Chang, P. and 8 co-authors (2008) Oceanic link between abrupt changes in the North Atlantic Ocean and the African monsoon. Nature GeoScience, Vol. 1, 444-448.

Chiang, J. C. H. and Bitz, C. M. (2005) Influence of high latitude ice cover on the marine Intertropical Convergence Zone. Climate Dynamics, Vol. 25, 477-496.

Christoforou, P. and Hameed, S. (1997) Solar cycle and the Pacific "centers of action." Geophysical Research Letters, Vol. 24, 293-296.

Claud, C., Duchiron, B., and Terray, P. (2008) On the associations between 11-year solar cycle and the Indian summer monsoon system. Journal of Geophysical Research, Vol. 113, doi:10.1029/2007JD008996.

Compo, G. P. and Sardeshmukh, P. D. (2008) Removing ENSO-related variations from the climate record. Journal of Climate, submitted.

Condron, A., Windsor, P., Hill, C., and Menemenlis, D. (2009) Simulated response of the Arctic freshwater budge to extreme NAO wind forcing. Journal of Climate, in press, doi:10.1175/2008JCLI2626.1.

Cuny, J., Rhines, P. B., and Kwok, R. (2005) Davis Strait volume, freshwater and heat fluxes. Deep Sea Research I, Vol. 52, 519-542.

Curry, R. G., McCartney, S., and Joyce, T. M. (1998) Oceanic transport of subpolar climate signals to mid-depth subtropical waters. Nature, Vol. 391, 575-577.

Darby, D. A. and Zimmerman, P. (2008) Ice-rafted detritus events in the Arctic the last glacial interval, and the timing of the Innuitian and Laurentide ice sheet calving events. Polar Research, Vol. 27, 114-127.

Davis, B. A. S., and Brewer, S. (2009) Orbital forcing and role of the latitudinal insolation/temperature gradient. Climate Dynamics, Vol. 32, 143-165.

Denton, G. H. and Broecker, W. S. (2008) Wobbly ocean conveyor circulation during the Holocene? Quaternary Science Reviews, Vol. 27, 1939-1950. 
Dickson, R., Rudels, B., Dye, S., Karcher, M., Meincke, J., and Yashayaev, I. (2007) Current estimates of freshwater flux through Arctic and subarctic seas. Progress in Physical Oceanography, Vol. 73, 210-230.

Di Lorenzo, E., Schneider, N., Cobb, K. M., Franks, P. J. S., Chhak, K., Miller, A. J., McWilliams, J. C., Bograd, S. J., Arango, H., Curchitser, E., Powell, T. M., and Riviere, P. (2008) North Pacific Gyre Oscillation links ocean climate and ecosystem change. Geophysical Research Letters, Vol. 35, doi:10.1029/ 2007 GL032838.

Dima, M. and Lohmann, G. (2007) A hemispheric mechanism for the Atlantic multidecadal oscillation. Journal of Climate, Vol. 20, 2706-2719.

Dima, M. and Lohmann, G. (2009) Conceptual model for millennial climate variability: A possible combined solar-thermohaline circulation origin for the 1,500-year cycle. Climate Dynamics, Vol. 32, 301-311.

Ding, Q. and Wang, B. (2005) Circumglobal teleconnection in the Northern Hemisphere summer. Journal of Climate, Vol. 18, 3483-3505.

Dong, B., Sutton, R. T., and Scaife, A. A. (2006) Multidecadal modulation of El Nino-Southern Oscillation (ENSO) variance by Atlantic Ocean sea surface temperatures. Geophysical Research Letters, Vol. 33, doi:10.1029/2006GL025766.

d'Orgeville, M. and Peltier, W. R. (2007) On the Pacific decadal oscillation and the Atlantic multidecadal oscillation: Might they be related? Geophysical Research Letters, Vol. 34, doi:10.1029/2007GL031584.

Dukhovskoy, D., Johnson, M., and Proshutinsky, A. (2006) Arctic decadal variability from an idealized atmosphere-ice-ocean model: 2. Simulation of decadal oscillations. Journal of Geophysical Research, Vol. 111, doi:10.1029/2004JC002820.

Eichler, A., Olivier, S., Henderson, S. K., Laube, A., Beer, J., Papina, T., Gaggler, H. W., and Schwikowski, M. (2009) Temperature response in the Altai region lags solar forcing. Geophysical Research Letters, Vol. 36, doi:10.1029/2008GL035930.

Emile-Geay, J., Cane, M., Seager, R., Kaplan, A., and Almasi, P. (2007) El Niño as a mediator of the solar influence on climate. Paleoceanography, Vol. 22, doi:10.1029/2006PA001304.

Feng, S. and Hu, Q. (2008) How the North Atlantic Multidecadal Oscillation may have influenced the Indian summer monsoon during the past two millennia. Geophysical Research Letters, Vol. 35, doi:10.1029/2007GL032484.

Giampapa, M. S., Hall, J. C., Radick, R. R., and Baliunas, S. L. (2006) A survey of chromospheric activity in the solar-type stars in the open cluster M67. The Astrophysical Journal, Vol. 651, 444-461.

Gil, I. M., Abrantes, F., and Hibbeln, D. (2006) The North Atlantic Oscillation forcing through the last 2000 years: Spatial variability as revealed by high-resolution marine diatom records from $\mathrm{N}$ and SW Europe. Marine Micropaleontology, Vol. 60, 113-129.

Goodkin, N. F., Hughen, K. A., Curry, W. B., Doney, S. C., and Ostermann, D. R. (2008a) Sea surface temperature and salinity variability at Bermuda during the end of the Little Ice Age. Paleoceanography, Vol. 23, doi:10.1029/2007PA001532.

Goodkin, N. F., Hughen, K. A., Doney, S. C., and Curry, W. B. (2008b) Increased multidecadal variability of the North Atlantic Oscillation since 1781. Nature Geoscience, Vol. 1, 844-848. 
Goodman, P. J. (2001) Thermohaline adjustment and advection in an OGCM. Journal of Physical Oceanography, Vol. 31, 1477-1497.

Goswami, B. N., Madhusoodanan, M. S., Neema, C. P., and Sengupta, D. (2006) A physical mechanism for North Atlantic SST influence on the Indian summer monsoon. Geophysical Research Letters, Vol. 33, doi:10.1029/2006GL024803.

Graversen, R. G., Mauritsen, T., Tjernstrom, M., Kallen, E., and Svensson, G. (2008) Vertical structure of recent Arctic warming. Nature, Vol. 541, 53-56.

Greene, C. H., Pershing, A. J., Cronin, T. M., and Ceci, N. (2008) Arctic climate change and its impacts on the ecology of the North Atlantic. Ecology, Vol. 89 Supplement, S24-S38.

Grosfeld, K., Lohmann, G., and Rimbu, N. (2008) The impact of Atlantic and Pacific Ocean sea surface temperature anomalies on the North Atlantic multidecadal variability. Tellus, Vol. 60A, 728-741.

Guan, Y. P. and Huang, R. X. (2008) Stommel's box model of thermohaline circulation revisited-the role of mechanical energy supporting mixing and the winddriven gyration. Journal of Physical Oceanography, Vol. 38, 909-917.

Hakkinen, S., Proshutinsky, A., and Ashik, I. (2008) Sea ice drift in the Arctic since the 1950s. Geophysical Research Letters, Vol. 35, doi:10.1029/2008GL034791.

Hall, J. C., Henry, G. W., and Lockwood, G. W. (2007) The sun-like activity of the solar twin 18 SCORPII. Astronomical Journal, Vol. 133, 2206-2208.

Hall, J. C. and Lockwood, G. W. (2004) The chromospheric activity and variability of cycling and flat activity solar-analog stars. The Astrophysical Journal, Vol. 614, 942-946.

Hall, J. C., Lockwood, G. W., and Skiff, B. A. (2007) The activity and variability of the Sun and sun-like stars. I. Synoptic Ca II H and K observations. Astronomical Journal, Vol. 133, 862-881.

Hasegawa, T., Yasuda, T., and Hanawa, K. (2007) Multidecadal variability of the upper ocean heat content anomaly field in the North Pacific and its relationship to the Aleutian Low and the Kuroshio Transport. Papers in Meteorology and Geophysics, Vol. 58, 155-166.

Hill, J. C., Gayes, P. T., Driscoll, N. W., Johnstone, E. A., and Sedberry, G. R. (2008) Iceberg scours along the southern U.S. Atlantic margin. Geology, Vol. 36, 447450.

Holland, D. M., Thomas, R. H., de Young, B., Ribergaard, M. H., and Lyberth, B. (2008) Acceleration of Jakobshavn Isbrae triggered by warm subsurface ocean waters. Nature Geoscience, Vol. 1, 659-664.

Holliday, N. P., Hughes, S. L., Bacon, S., Beszczynska-Moller, A., Hansen, B., Lavin, A., Loeng, H., Mork, K. A., Osterhus, S., Sherwin, T., and Walczowski, W. (2008) Reversal of the 1960s to 1990s freshening trend in the northeast North Atlantic and Nordic Seas. Geophysical Research Letters, Vol. 35, doi:10.1029/2008GL032675.

Holzkamper, S., Mangini, A., Spotl, C., and Mudelsee, M. (2004) Timing and progression of the Last Interglacial derived from a high alpine stalagmite. Geophysical Research Letters, Vol. 31, doi:10.1029/2003GL019112.

Hoyt, D. V. and Schatten, K.H. (1993) A discussion of plausible solar irradiance variations, 1700-1992. Journal of Geophysical Research, Vol. 98, 18,89518,906 . 
Huth, R., Pokorna, L., Bochnicek, J., and Hejda, P. (2006) Solar cycle effects on modes of low-frequency circulation variability. Journal of Geophysical Research, Vol. 111, doi:10.1029/2005JD006813.

Huybers, P. and Curry, W. (2006) Links between annual, Milankovitch, and continuum temperature variability. Nature, Vol. 441, 329-332.

Huybers, P. and Denton, G. (2008) Antarctic temperature at orbital timescales controlled by local summer duration. Nature Geoscience, Vol. 1, 787-792.

IPCC (2007) Chapter 2 by Forster, P., Ramaswamy, V., Artaxo, P., Berntsen, T., Betts, R., Fahey, D. W., Haywood, J., Lean, J., Lowe, D. C., Myhre, G., Nganga, J., Prinn, R., Raga, G., Schulz, M., and Van Dorland, R., Changes in atmospheric constituents and in radiative forcing. In S. Solomon, D. Qin, M. Manning, Z. Chen, M. Marquis, K. B. Avery, M. Tignor, and H. L. Miller, eds., Climate Change 2007: The Physical Science Basis. Cambridge, UK and New York, NY: Cambridge University Press, Contribution of Working Group I to the Fourth Assessment Report of the Intergovernmental Panel on Climate Change.

Jain, S., Lall, U., and Mann, M. E. (1999) Seasonality and interannual variations of Northern Hemisphere temperature: Equator-to-pole gradient and ocean-land contrast. Journal of Climate, Vol. 12, 1086-1100.

Jiang, H., Eiriksson, J., Schulz, M., Knudsen, K.-L., and Seidenkrantz, M.-S. (2005) Evidence for solar forcing of sea-surface temperature on the North Icelandic Shelf duing the late Holocene. Geology, Vol. 33, 73-76.

Johannessen, O. M., Bengtsson, L., Miles, M. W., Kuzmina, S. I., Semenov, V. A., Alekseev, G. V., Nagurnyi, A. P., Zakharov, V. F., Bobylev, L. P., Pettersson, L. H., Hasselmann, K., and Cattle, H. P. (2004) Arctic climate change: Observed and modeled temperature and sea-ice variability. Tellus, Vol. 56A, 328-341.

Jones, E. P., Swift, J. H., Anderson, L. G., Lipizer, M., Civitarese, G., Falkner, K. K., Kattner, G., and McLaughlin, F. (2003) Tracing Pacific water in the North Atlantic Ocean. Journal of Geophysical Research, Vol. 108, doi:10.1029/2001JC001141.

Jungclaus, J. H., Haak, H., Latif, M., and Mikolajewicz, U. (2005) Arctic-North Atlantic interactions and multidecadal variability of the meridional overturning circulation. Journal of Climate, Vol. 18, 4013-4031.

Kauker, F., Koberle, C., Gerdes, R., and Karcher, M. (2008) Modeling the $20^{\text {th }}$ century Arctic ocean/sea ice system: Reconstruction of surface forcing. Journal of Geophysical Research, Vol. 113, doi:10.1029/2006JC004023.

Keigwin, L. D. and Cook, M. S. (2007) A role for North Pacific salinity in stabilizing North Atlantic climate. Paleoceanography, Vol. 22, doi:10.1029/2007PA001420.

Knight, J. R., Allan, R. J., Folland, C. K., Velinga, M., and Mann, M. E. (2005) A signature of persistent natural thermohaline circulation cycles in observed climate. Geophysical Research Letters, Vol. 32, doi:10.1029/2005GL024233.

Knight, J. R., Folland, C. K., and Scaife, A. A. (2006) Climatic impacts of the Atlantic multidecadal oscillation. Geophysical Research Letters, Vol. 33, doi:10.1029/ 2006 GL026242.

Kodera, K. (2004) Solar influence on the Indian Ocean monsoon through dynamical processes. Geophysical Research Letters, Vol. 31, doi:10.1029/2004GL020928. 
Kodera, K. and Shibata, K. (2006) Solar influence on the tropical stratosphere and troposphere in the northern summer. Geophysical Research Letters, Vol. 33, doi:10.1029/2006GL026659.

Kravtsov, S. and Spannagle, C. (2008) Multidecadal climate variability in observed and modeled surface temperatures. Journal of Climate, Vol. 21, 1104-1121.

Kwok, R. (2006) Exchange of sea ice between the Arctic Ocean and the Canadian Arctic Archipelago. Geophysical Research Letters, Vol. 33, doi:10.1029/ 2006GL027094.

Kwok, R. (2007) Baffin Bay ice drift and export: 2002-2007. Geophysical Research Letters, Vol. 34, doi:10.1029/2007GL031204.

Latif, M., Boning, C., Willebrand, J., Biastoch, A., Dengg, J., Keenlyside, N., Schweckendiek, U., and Madec, G. (2006) Is the thermohaline circulation changing? Journal of Climate, Vol. 19, 4631-4637.

Latif, M., Roeckner, E., Esch, M., Haak, H., Hagemann, S., Jungclaus, J., Legutke, S., Marsland, S., Mikolajewicz, U., and Mitchell, J. (2004) Reconstructing, monitoring, and predicting multidecadal-scale changes in the North Atlantic thermohaline circulation with sea surface temperature. Journal of Climate, Vol. 17, 16051614.

Lean, J. (2000) Evolution of the Sun's spectral irradiance since the Maunder Minimum. Geophysical Research Letters, Vol. 27, 2425-2428.

Lean, J., Beer, J., and Bradley, R. (1995) Reconstruction of solar irradiance since 1610: Implications for climate change. Geophysical Research Letters, Vol. 22, 3195-3198.

L'Heureux, M. L., Kumar, A., Bell, G. D., Halpert, M. S., and Higgins, R. W. (2008) Role of the Pacific-North American (PNA) pattern in the 2007 Arctic sea ice decline. Geophysical Research Letters, Vol. 35, doi:10.1029/2008GL035205.

Li, S. and Bates, G. T. (2007) Influence of Atlantic multidecadal oscillation on the winter climate of East China. Advances in Atmospheric Sciences, Vol. 24, 126135.

Li, S., Perlwitz, J., Quan, X., and Hoerling, M. P. (2008) Modeling the influence of North Atlantic multidecadal warmth on the Indian summer rainfall. Geophysical Research Letters, Vol. 35, doi:10.1029/2008GL032901.

Lim, G.-H., Suh, Y.-C. , and Kim, B.-M. (2006) On the origin of the topical Atlantic decadal oscillation based on the analysis of the ICOADS. Quarterly Journal of the Royal Meteorological Society, Vol. 132, 1139-1152.

Lindsay, R. W., Zhang, J., Schweiger, A., Steele, M., and Stern, H. (2009) Arctic sea ice retreat in 2007 follows thinning trend. Journal of Climate, Vol. 22, 165-176.

Lindzen, R. S. (1994) Climate dynamics and global change. Annual Review of Fluid Mechanics, Vol. 26, 353-378.

Lockwood, G. W., Skiff, B. A., Henry, G. W., Henry, S., Radick, R. R., Baliunas, S. L., Donahue, R. A., and Soon, W. (2007) Patterns of photometric and chromospheric variation among sun-like stars: A 20- year perspective. The Astrophysical Journal Supplementary Series, Vol. 171, 260-303.

Loutre, M. F., Berger, A., Bretagnon, P., and Blanc, P.-L. (1992) Astronomical frequencies for climate research at the decadal to century time scale. Climate Dynamics, Vol. 7, 181-194. 
Lu, R., Dong, B., and Ding, H. (2006) Impact of Atlantic multidecadal oscillation on the Asian summer monson. Geophysical Research Letters, Vol. 33, doi:10.1029/ 2006 GL027655.

Meehl, G. A., Arblaster, J. M., Branstator, G., and van Loon, H. (2008) A coupled air-sea response mechanism to solar forcing in the Pacific region. Journal of Climate, Vol. 21, 2883-2897.

Molinari, R. L., Fine, R. A., Wilson, W. D., Curry, R. G., Abell, J., and McCartney, S. (1998) The arrival of recently formed Labrador Sea Water in the Deep Western Boundary Current at $26.5^{\circ} \mathrm{N}$. Geophysical Research Letters, Vol. 25, 2249-2252.

Moon, S. and Johnson, M. A. (2005) The relationship between $0^{\circ} \mathrm{C}$ isotherm and atmospheric forcing in the Arctic Ocean. Geophysical Research Letters, Vol. 32, doi:10.1029/2005GL023213.

Moros, M., Andrews, J. T., Eberl, D., and Jansen, E. (2006) Holocene history of drift ice in the northern North Atlantic: Evidence for different spatial and temporal modes. Paleoceanography, Vol. 22, doi:10.1029/2005PA001214.

Munchow, A., Melling, H., and Falkner, K. K. (2006) An observational estimate of volume and freshwater flux leaing the Arctic Ocean through Nares Strait. Journal of Physical Oceanography, Vol. 36, 2025-2041.

Nilsson, J., Brostrom, G., and Walin, G. (2003) The thermohaline circulation and vertical mixing: Does weaker density stratification give stronger overturning? Journal of Physical Oceanography, Vol. 33, 2781-2795.

Nilsson, J. and Walin, G. (2001) Freshwater forcing as a booster of thermohaline circulation. Tellus, Vol. 53A, 629-641.

Nyberg, J., Kuijpers, A., Malmgren, B. A., and Kunzendorf, H. (2001) Late Holocene changes in precipitation and hydrography recorded in marine sediments from northeastern Caribbean Sea. Quaternary Research, Vol. 56, 87-102.

Overland, J. E., Wang, M., and Salo, S. (2008) The recent Arctic warm period. Tellus, Vol. 60A, 587-597.

Pardaens, A., Vellinga, M., Wu, P., and Ingleby, B. (2008) Large-scale Atlantic salinity changes over the last half-century: A model-observation comparison. Journal of Climate, Vol. 21, 1698-1720.

Park, W. and Latif, M. (2008) Multidecadal and multicentennial variability of the meridional overturning circulation. Geophysical Research Letters, Vol. 35, doi:10.1029/2008GL035779.

Pavlakis, K. G., Hatzianastassiou, N., Matsoukas, C., Fotiadi, A., and Vardavas, I. (2008) ENSO surface shortwave radiation forcing over the tropical Pacific. Atmospheric Chemistry and Physics, Vol. 8, 5565-5577.

Peterson, B. J., McClelland, J., Curry, R., Holmes, R. M., Walsh, J. E., and Aagaard, K. (2006) Trajectory shifts in the Arctic and subArctic freshwater cycle. Science, Vol. 313, 1061-1066.

Peterson, L. C. and Haug, G. H. (2006) Variability in the mean latitude of the Atlantic Intertropical Convergence Zone as recorded by riverine input of sediments to the Cariaco Basin (Venezuela). Palaeogeography, Palaeoclimatology, Palaeoecology, Vol. 234, 97-113.

Polyakov, I. V., Alexeev, V. A., Belchansky, G. I., Dmitrenko, I. A., Ivanov, V. V., Kirillov, S. A., Korablev, A. A., Steele, M., Timokhov, L. A., and Yashayaev, I. 
(2008) Arctic ocean freshwater changes over the past 100 years and their causes. Journal of Climate, Vol. 21, 364-384.

Polyakov, I. V., Beszczynska, A., Carmack, E. C., Dmitrenko, I. A., Fahrbach, E., Frolov, I. E., Gerdes, R., Hansen, E., Holfort, J., Ivanov, V. V., Johnson, M. A., Karcher, M., Kauker, F., Morison, J., Orvik, K. A., Schauer, U., Simmons, H. L., Skagseth, O., Sokolov, V. T., Steele, M., Timokhov, L. A., Walsh, D., and Walsh, J. E. (2005) One more step toward a warmer Arctic. Geophysical Research Letters, Vol. 32, doi:10.1029/2005GL023740.

Poore, R. Z., Quinn, T. M., and Verardo, S. (2004) Century-scale movement of the Atlantic Intertropical Convergence Zone linked to solar variabilty. Geophysical Research Letters, Vol. 31, doi:10.1029/2004GL019940.

Portis, D. H., Walsh, J. E., Hamly, M. E., and Lamb, P. J. (2001) Seasonality of the North Atlantic Oscillation. Journal of Climate, Vol. 14, 2069-2078.

Prinsenberg, S. J. and Hamilton, J. (2005) Monitoring the volume, freshwater and heat fluxes passing through Lancaster Sound in the Canadian Arctic Archipelago. Atmosphere-Ocean, Vol. 43, 1-22.

Proshutinsky, A., Bourke, R. H., and McLaughlin, F. A. (2002) The role of the Beaufort Gyre in Arctic climate variability: Seasonal to decadal climate scales. Geophysical Research Letters, Vol. 29, doi:10.1029/2002GL015847.

Qiu, B., Schneider, N., and Chen, S. (2007) Coupled decadal variability in the North Pacific: An observationally constrained idealized model. Journal of Climate, Vol. 20, 3602-3620.

Radick, R. R., Lockwood, G. W., Skiff, B. A., and Baliunas, S. L. (1998) Patterns of variation among Sun-like stars. The Astrophysical Journal Supplementary Series, Vol. 118, 239-258.

Rind, D. (2008) The consequences of not knowing low- and high-latitude climate sensitivity. Bulletin of the American Meteorological Society, Vol. 89, 855-864.

Rodionov, S. N., Overland, J. E., and Bond, N. A. (2005) The Aleutian Low and winter climatic conditions in the Bering Sea. Part I: Classification. Journal of Climate, Vol. 18, 160-177.

Saenko, O. A. (2009) On the climatic impact of wind stress. Journal of Physical Oceanography, Vol. 39, 89-106.

Scafetta, N. and Willson R. (2009) ACRIM-gap and TSI trend issue resolved using a surface magnetic flux TSI proxy model. Geophysical Research Letters, in press, doi:10.1029/2008GL036307.

Selten, F. M., Branstator, G. W., Dijkstra, H. A., and Kliphuis, M. (2004) Tropical origins for recent and future Northern Hemisphere climate change. Geophysical Research Letters, Vol. 31, doi:10.1029/2004GL020739.

Serreze, M. C., Barrett, A. P., Slater, A. G., Woodgate, R. A., Aagaard, K., Lammers, R. B., Steele, M., Moritz, R., Meredith, M., and Lee, C. M. (2006) The large-scale freshwater cycle of the Arctic. Journal of Geophysical Research Letters, Vol. 111, doi:10.1029/2005JC003424.

Serreze, M. C., Barrett, A. P., Stroeve, J. C., Kindig, D. N., and Holland, M. M. (2008) The emergence of surface-based Arctic amplification. The Cryosphere Discussion, Vol. 2, 601-622. 
Shimada, K., Kamoshida, T., Itoh, M., Nishino, S., Carmack, E., McLaughlin, F., Zimmermann, S., and Proshuntinsky, A. (2006) Pacific Ocean inflow: Influence on catastrophic reduction of sea ice cover in the Arctic Ocean. Geophysical Research Letters, Vol. 33, doi:10.1029/2005GL025624.

Smedsrud, L. H., Sorteberg, A., and Kloster, K. (2008) Recent and future changes of the Arctic sea-ice cover. Geophysical Research Letters, Vol. 35, doi:10.1029/ 2008 GL034813.

Soderkvist, J. and Bjork, G. (2004) Ice thickness variability in the Arctic Ocean between 1954-1990, results from a coupled ocean-ice-atmosphere column model. Climate Dynamics, Vol. 22, 57-68.

Soon, W. W.-H. (2005) Variable solar irradiance as a plausible agent for multidecadal variations in the Arctic-wide surface air temperature record of the past 130 years. Geophysical Research Letters, Vol. 32, doi:10.1029/2005GL023429.

Soon, W. (2007) Implications of the secondary role of carbon dioxide and methane forcing in climate change: Past, present, and future. Physical Geography, Vol. 28, 97-125.

Soon, W., Baliunas, S., Posmentier, E. S., and Okeke, P. (2000) Variations of solar coronal hole area and terrestrial lower tropospheric air temperature from 1979 to mid-1998: Astronomical forcings of change in Earth's climate? New Astronomy, Vol. 4, 563-579.

Stanhill, G. and Cohen, S. (2008) Solar radiation changes in Japan during the $20^{\text {th }}$ century: Evidence from sunshine duration measurements. Journal of the Meteorological Society of Japan, Vol. 86, 57-67.

Stott, L., Poulsen, C., Lund, S, and Thunell, R. (2002) Super ENSO and global climate oscillations at millennial time scales. Science, Vol. 297, 222-226 (with erratum published in the October 25, 2002 issue).

Sutton, R. T., and Hodson, D. L. R. (2007) Climate response to basin-scale warming and cooling of the North Atlantic Ocean. Journal of Climate, Vol. 20, 891-907.

Tan, M., Hou, J., and Liu, T. (2004) Sun-coupled climate connection between eastern Asia and northern Atlantic. Geophysical Research Letters, Vol. 31, doi: 10.1029/2003GL019085.

Timmermann, A., Okumura, Y., An, S.-I., Clement, A., Dong, B., Guilyardi, E., Hu, A., Jungclaus, J. H., Renold, M., Stocker, T. F., Stouffer, R. J., Sutton, R., Xie, S.-P., and Yin, J. (2007) The influence of a weakening of the Atlantic meridional overturning circulation on ENSO. Journal of Climate, Vol. 20, 4899-4919.

Ting, M., Kushnir, Y., Seager, R., and Li, C. (2008) Forced and internal $20^{\text {th }}$ century SST trends in the North Atlantic. Journal of Climate, doi:10.1175/2008JCLI2561.1.

Toggweiler, J. R. and Russell, J. (2008) Ocean circulation in a warming climate. Nature, Vol. 451, 286-288.

Tung, K. K. and Camp, C. D. (2008) Solar cycle warming at the Earth's surface in NCEP and ERA-40 data: A linear discriminant analysis. Journal of Geophysical Research, Vol. 113, doi:10.1029/2007JD009164.

Usoskin, I. G., Berdyugina, S. V., Moss, D., and Sokoloff, D. D. (2007) Long-term persistence of solar active longitudes and its implications for the solar dynamo theory. Advances in Space Research, Vol. 40, 951-958. 
Vage, K., Pickart, R. S., Thierry, V., Reverdin, G., Lee, C. M., Petrie, B., Agnew, T. A., Wong, A., and Ribergaard, M. H. (2009) Surprising return of deep convection to the subpolar North Atlantic Ocean in winter 2007-2008. Nature Geoscience, Vol. 2, 67-72.

van Loon, H. and Meehl, G. A. (2008) The response in the Pacific to the sun's decadal peaks and contrasts to cold events in the Southern Oscillation. Journal of Atmospheric and Solar-Terrestrial Physics, Vol. 70, 1046-1055.

Vellinga, M. and Wu, P. (2004) Low-latitude freshwater influence on centennial variability of the Atlantic thermohaline circulation. Journal of Climate, Vol. 17, 4498-4511.

Vidal, L., Labeyrie, L. Cortijo, E., Arnold, M. Duplessy, J.-C., Michel, E., Becque, S., and van Weering, T. C. E. (1997) Evidence for changes in the North Atlantic Deep water linked to meltwater surges during the Heinrich events. Earth and Planetary Science Letters, Vol. 146, 13-27.

Visbeck, M. (2007) Power of pull. Nature, Vol. 447, 383.

Wadley, M. R. and Bigg, G. R. (2002) Impact of flow through the Canadian Archipelago and Bering Strait on the North Atlantic and Arctic circulation: An ocean modeling study. Quarterly Journal of the Royal Meteorological Society, Vol. 128, 2187-2203.

Wang, Y., Cheng, H., Edwards, R. L., Kong, X., Shao, X., Chen, S., Wu, J., Jiang, X., Wang, X., and An, Z. (2008) Millennia- and orbital-scale changes in the East Asian monsoon over the past 224,000 years. Nature, Vol. 451, 1090-1093.

Wang, Y., Li, S., and Luo, D. (2009) Seasonal response of Asian monsoonal climate to the Atlantic Multidecadal Oscillation. Journal of Geophysical Research, doi:10.1029/2008JD010929, in press.

Wang, Y.-M., Lean, J. L., and Sheeley, N. R., Jr. (2005) Modeling the Sun's magnetic field and irradiance since 1713. The Astrophysical Journal, Vol. 625, 522-538.

Watanabe, M. (2004) Asian jet waveguide and a downstream extension of the North Atlantic Oscillation. Journal of Climate, Vol. 17, 4674-4691.

Weng, H. (2005) The influence of the $11 \mathrm{yr}$ solar cycle on the interannualcentennial climate variability. Journal of Atmospheric and Solar-Terrestrial Physics, Vol. 67, 793-805.

White, W. B. and Liu, Z. (2008a) Resonant excitation of the quasi-decadal oscillation by the 11-yr signal in the Sun's irradiance. Journal of Geophysical Research, Vol. 113, doi:10.1029/2006JC004057.

White, W. B. and Liu, Z. (2008b) Non-linear alignment of El Nino to the 11-yr solar cycle. Geophysical Research Letters, Vol. 35, doi:10.1029/2008GL034831.

Winton, M. (2006) Amplified Arctic climate change: What does surface albedo feedback have to do with it? Geophysical Research Letters, Vol. 33, doi:10.1029/ 2005 GL025244.

Wu, L., Liu, Z., Gallimore, R., Jacob, R., Lee, D., and Zhong, Y. (2003) Pacific decadal variability: The Tropical Pacific mode and the North Pacific mode. Journal of Climate, Vol. 16, 1101-1120.

Wu, P. and Wood, R. (2008) Convection induced long term freshening of the subpolar North Atlantic ocean. Climate Dynamics, Vol. 31, 941-956. 
Wu, Z., Schneider, E. K., Kirtman, B. P., Sarachik, E. S., Huang, N. E., and Tucker, C. J. (2008) The modulated annual cycle: An alternative reference frame for climate anomalies. Climate Dynamics, Vol. 31, 823-841.

Yang, J. (1999) A linkage between decadal climate variations in the Labrador Sea and the tropical Atlantic Ocean. Geophysical Research Letters, Vol. 26, 10231026.

Yang, J. (2005) The Arctic and subarctic Ocean flux of potential vorticity and the Arctic Ocean circulation. Journal of Physical Oceanography, Vol. 35, 23872407.

Yang, J. (2006) The seasonal variability of the Arctic Ocean Ekman transport and its role in the mixed layer heat and salt fluxes. Journal of Climate, Vol. 19, 53665387.

Yashayaev, I. (2007) Hydrographic changes in the Labrador Sea, 1960-2005. Progress in Physical Oceanography, Vol. 73, 242-276.

Yashayaev, I., Bersch, M., and van Aken, H. M. (2007) Spreading of the Labrador Sea water to the Irminger and Iceland basins. Geophysical Research Letters, Vol. 34, doi:10.1029/2006GL028999.

Yashayaev, I. and Loder, J. W. (2009) Enhanced production of the Labrador Sea water in 2008. Geophysical Research Letters, Vol. 36, doi:10.1029/2008GL036162.

Zhang, Q., Soon, W. H., Baliunas, S. L., Lockwood, G. W., Skiff, B. A., and Radick, R. R. (1994) A method of determining possible brightness variations of the Sun in past centuries from observations of solar-type stars. The Astrophysical Journal Letters, Vol. 427, L111-L114.

Zhang, R. and Delworth, T. L. (2005) Simulated tropical response to a substantial weakening of the Atlantic thermohaline circulation. Journal of Climate, Vol. 18, 1853-1860.

Zhang, R. and Delworth, T. L. (2007) Impact of the Atlantic multidecadal oscillation on North Pacific climate variability. Geophysical Research Letters, Vol. 34, doi: 10.1029/2007GL031601.

Zhang, R., Delworth, T. L., and Held, I. M. (2007) Can the Atlantic Ocean drive the observed multidecadal variability in Northern Hemisphere mean temperature? Geophysical Research Letters, Vol. 34, doi:10.1029/2006GL028683.

Zhang, R., and Vallis, G. K. (2006) Impact of Great Salinity Anomalies on the lowfrequency variability of the North Atlantic climate. Journal of Climate, Vol. 19, 470-482.

Zhang, X., Sorteberg, A., Zhang, J., Gerdes, R., and Comiso, J. C. (2008) Recent radical shifts of atmospheric circulations and rapid changes in Arctic climate system. Geophysical Research Letters, Vol. 35, doi:10.1029/2008GL035607.

Zhou, H. and 8 co-authors (2008) Decoupling of stalagmite-derived Asian summer monsoon records from North Atlantic temperature change during marine oxygen isotope stage 5d. Quaternary Research, Vol. 70, 315-321.

Zweng, M. M. and Munchow, A. (2006) Warming and freshening of Baffin Bay, 1916-2003. Journal of Geophysical Research Letters, Vol. 111, doi:10.1029/ 2005JC003093. 


\section{NOTES}

${ }^{1}$ Huth et al. (2006) cautioned that it may not be appropriate to use spatially fixed indices, such as the North Atlantic Oscillation (NAO; see however the study of Portis et al., 2001 for a new NAO index with spatially evolving domains) to study plausible solar activity responses since the majority of COAs change their locations depending on the solar cycle phases. In addition, Rodionov et al. (2005), in their careful classification of five types of atmospheric circulation for anomalously warm months and another five types for anomalously cold months in the Bering Sea, found that changes in the position of the Aleutian Low are more important than changes in its central pressure.

${ }^{2}$ The high alpine stalagmite $\delta^{18} \mathrm{O}$ record of Holzkamper et al. (2004) covering the Eemian, however, still shows evidence for spectral peaks at 197, 109, and 21 years that can be associated with the Suess/ deVries, Gleissberg, and Hale cycles of solar activity variations.

${ }^{3}$ White and Liu (2008b) recently reported how the 11-year solar radiative forcing drove not only the quasi-decadal signal in the tropical Pacific sea surface temperature (White and Liu, 2008a) but also was responsible for the 3.6-year ENSO signal and the 2.2-year quasi-biennial-oscillation signal. The 3.6year and 2.2-year SST signals are interpreted and modeled as the third and fifth harmonics of the firstharmonic 11-year period quasi-decadal response to the 11-year solar radiative forcing. Usoskin et al. (2007) provided additional discussion and consideration of intrinsic solar activity variations on the interannual timescale, including the persistence of the third harmonics of the 11-year solar cycles.

${ }^{4}$ One should note that the absolute level of TSI since 1979 has been measured by satellite-borne cavity radiometers with values ranging from 1360 to $1375 \mathrm{~W} / \mathrm{m}^{2}$, and the resolution of this indeterminacy requires new measurements with radiometers with more precisely determined pinhole area versus surface area of the cavity radiometers. The absolute value of TSI used for this paper has been arbitrarily tuned so that the mean value for the 1979-present interval is roughly $1366.3 \mathrm{~W} / \mathrm{m}^{2}$ (N. Scafetta, 2007, private comm.; Scafetta and Willson, 2009).

To further comment on the estimates of TSI forcing, the IPCC (2007) AR4 WG 1 report's Section 2.7 (p. 188) has recently claimed:

The estimates of long-term solar irradiance changes used in the TAR (e.g., Hoyt and Schatten, 1993; Lean et al., 1995) have been revised downwards, based on new studies indicating that bright solar faculae likely contributed a smaller irradiance increase since the Maunder Minimum than was originally suggested by the range of brightness in Sunlike stars (Hall and Lockwood, 2004; M. [sic] Wang et al., 2005).

Figure 2.17 on p. 190 of the IPCC (2007) WG 1 report provides a graphical summary that contrasts the previous estimate by Lean (2000) to the new estimate by Y.-M. Wang et al. (2005; including Lean as co-author). The comparison shows that the older estimate was 3.8 times larger for the deduced increase of radiative forcing from the Maunder Minimum to contemporary solar activity minima.

But is the quoted claim correct? Several facts clearly suggest that those statements from IPCC AR4 are neither accurate nor authoritative. First, it must be pointed out that, although Y.-M. Wang et al. (2005) may have given the impression that their paper actually gives a constraint on how large or small the brightness of the Sun should be, it does not. Their paper was based primarily on the so-called magnetic flux transport model that was never meant to model any irradiance change or any assessment of the energy budget of the whole Sun. The flux transport model does not even contain any radiative transfer calculation.

A similar limitation can be noted in the IPCC AR4's reference to Hall and Lockwood (2004), which was primarily a paper on solar and stellar magnetic activity rather than on how magnetism and light outputs of the Sun and sunlike stars are linked. Furthermore, it is somewhat puzzling that the following related papers were not cited or discussed: (1) Radick et al. (1998); (2) Giampapa et al. (2006); (3) Hall, Henry et al. (2007); 4) Hall, Lockwood, et al. (2007); and (5) Lockwood et al. (2007). The IPCC AR4 WG I Chapter 2 authors also ignored the key result published in Zhang et al. (1994) [previously cited in IPCC (2001) Third Assessment Report] that is clearly not outdated or superceded. Therefore, the IPCC AR4 quote highlighted here is not a defensible summary of the high-quality scientific research that has been done on TSI forcing. 
${ }^{5}$ See the discussion in Vage et al. (2009) on the multiple factors contributing to the return of deep convection at the Labrador and Irminger seas during the winter season of 2007-2008 despite a fairly low or neutral NAO index and an increased flux of Arctic sea ice to the North Atlantic subpolar basin.

${ }^{6}$ Based on a study of the unforced internal variability of the Kiel Climate Model, Park and Latif (2008) recently proposed the separation of their "multidecadal-scale" (i.e., with peak spectral powers at roughly 50-100 years) and "multicentennial-scale" (i.e., with peak spectral powers at roughly 300-400 years) variability of the Atlantic MOC, in that the former can be shown to originate in the North Atlantic whereas the latter is driven in the Southern Ocean. The current state of ocean proxy-observation and modeling does not meaningfully warrant such a distinction at this time.

${ }^{7}$ See also discussion and estimates in Wadley and Bigg (2002), Jones et al. (2003), Cuny et al. (2005), Prinsenberg and Hamilton (2005), Kwok (2006, 2007), Munchow et al. (2006), Serreze et al. (2006), Zweng and Munchow (2006), Greene et al. (2008), and Condron et al. (2009).

${ }^{8}$ This dipole index was defined as the difference of the annual-mean SSTs from the $40-60^{\circ} \mathrm{N}, 60$ $10^{\circ} \mathrm{W}$ box and $40-60^{\circ} \mathrm{S}, 50^{\circ} \mathrm{W}-0^{\circ}$ box in Latif et al. (2006), and is slightly different from a previous definition of the difference between the $40-60^{\circ} \mathrm{N}, 50-10^{\circ} \mathrm{W}$ box and $10-40^{\circ} \mathrm{S}, 50^{\circ} \mathrm{W}-10^{\circ}$ box by Latif et al. (2004).

${ }^{9}$ See Guan and Huang (2008) for additional clarification on the key role played by wind stress and tidal dissipation as the external mechanical sources needed to support the MOC/THC, and see Adkins et al. (2005) for a suggestion of the thermobaric effects and geothermal heating in explaining the rapid change and instability observed for glacial deep ocean.

${ }^{10}$ See Bond et al. (1997) and Bond et al. (1999) for the discussion of the muted Dansgaard/ Oeschger-like mode during the Holocene. See also the distinction and clarification for rapid and abrupt oscillations during glacial times and the Holocene in Alley (2007) and Denton and Broecker (2008).

${ }^{11}$ Weng (2005) was referring to the "80-90 Gleissberg cycle" timescale, but I agree with her that it is probably difficult or even pointless to be too specific because the objective of our common task is to understand not only any particular spectral features/characteristics, but also the broader scales of the weather-climate continuum.

${ }^{12}$ See Braun et al. (2008) for additional supports and arguments for their original paper. 


\section{APPENDIX 1}

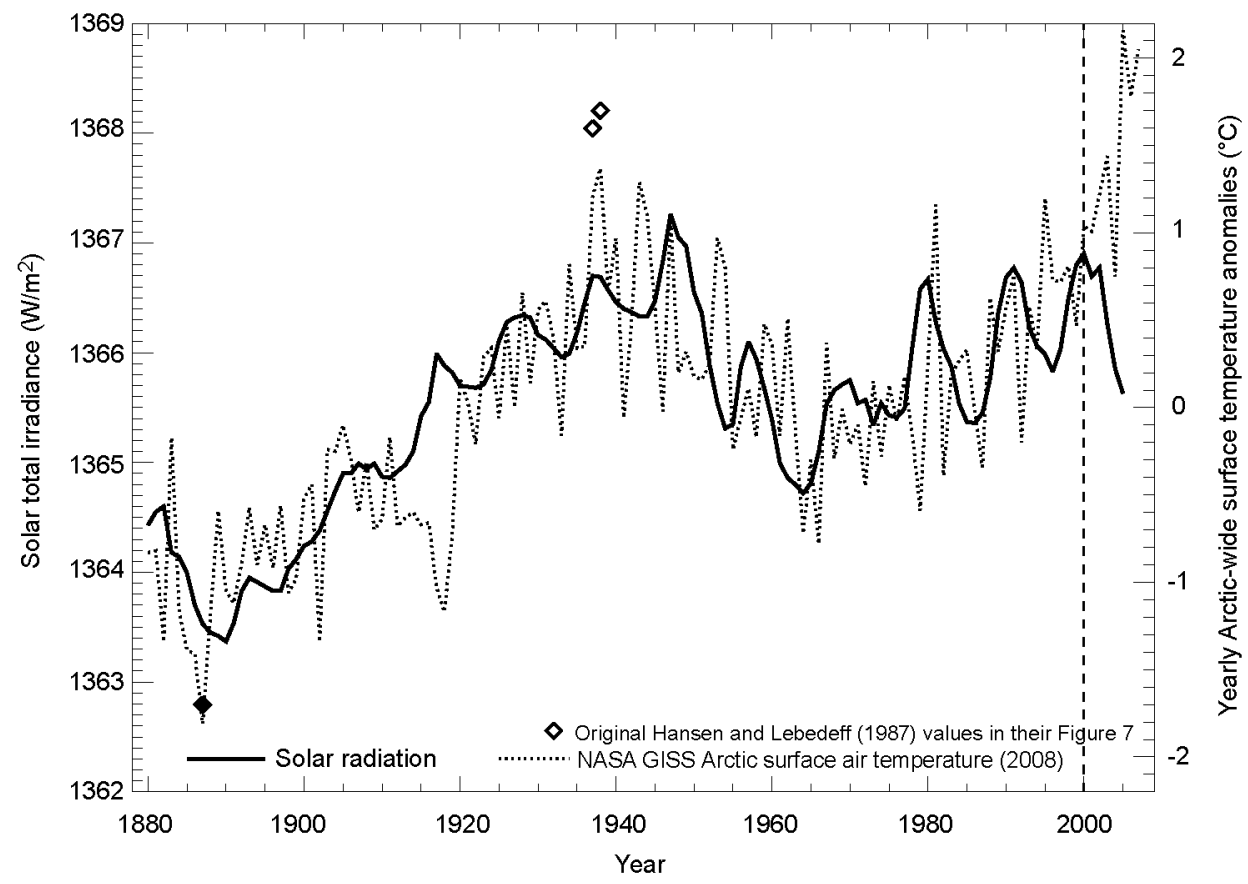

Fig. A1. Updated annual mean Arctic surface air temperature anomaly (dotted line) time series (from NASA GISS) correlated with the estimated total solar irradiance (solid line) of Hoyt and Schatten (1993) from 1880-2007. It should be noted that an updated time series from Polyakov et al. (2003) is unavailable at this time (Polyakov, private comm., July 24, 2008), so the NASA GISS Arctic $\left(64-90^{\circ} \mathrm{N}\right)$ temperature series (http://data.giss.nasa.gov/gistemp/tabledata/ZonAnn.Ts+dSST.txt) is adopted for convenience. Although not strongly affecting the current study on multidecadal to centennial variability, there are apparent discrepancies between the relative highs of the Arctic temperature values for 1937 and 1938 in the current NASA GISS database compared to previously published values (marked by the open diamond symbols) from Hansen and Lebedeff (1987). In contrast, the value for the cool year at 1887 remained similar (closed diamond symbol) from the old and new NASA GISS records. It is not obvious how the urban heat island effect can play a dominant role in either the Arctic surface air temperature record of Polyakov et al. (2003) or NASA GISS. The vertical dashed line around the year 2000 marks the end year for the previously published result in Soon (2005). 


\section{APPENDIX 2}

Table A1. References on Sun-Climate Oscillation Scales Detected in Multiproxy Archives with a Focus on the 80-Year and 200-Year (and the necessary 1500-year scale) Solar Variability

\begin{tabular}{|c|c|c|c|c|c|}
\hline Reference & Location & Data & Proxy & Time intervals & $\begin{array}{l}\text { Scales of vari- } \\
\text { ability detected }\end{array}$ \\
\hline \multicolumn{6}{|c|}{ (0) Solar proxies and theories } \\
\hline Pipin, 1999 & Sun & Dynamo theory & $\begin{array}{l}\text { Solar } \\
\text { magnetism }\end{array}$ & General & $\begin{array}{c}\text { Gleissberg and } \\
\text { longer scales }\end{array}$ \\
\hline $\begin{array}{l}\text { Wagner et al., } \\
2001\end{array}$ & $\begin{array}{l}\text { Greenland } \\
\text { GRIP }\end{array}$ & ${ }^{10}$ Be ice-core & $\begin{array}{l}{ }^{10} \text { Be produc- } \\
\text { tion rate }\end{array}$ & 20-50 kyr B.P. & $205-y r$ \\
\hline $\begin{array}{l}\text { Peristykh and } \\
\text { Damon, } 2003\end{array}$ & World & $\begin{array}{c}\Delta{ }^{14} \mathrm{C} \text { tree-ring } \\
\text { chronology }\end{array}$ & $\begin{array}{l}{ }^{14} \mathrm{C} \text { production } \\
\text { rate }\end{array}$ & Last 12,000 yrs & $\begin{array}{l}\text { 88-yr, 208-yr, } \\
2304-y r\end{array}$ \\
\hline $\begin{array}{l}\text { Vonmoos et al., } \\
\text { 2006; } \\
\text { Vonmoos, } \\
2005 \text { Ph.D. } \\
\text { thesis }\end{array}$ & GRIP & ${ }^{10} \mathrm{Be}$ & $\begin{array}{l}{ }^{10} \mathrm{Be} \\
\text { production } \\
\text { rate }\end{array}$ & $\begin{array}{l}\text { 304-9315 yr } \\
\text { B.P. }\end{array}$ & $88-y r, 205-y r$ \\
\hline $\begin{array}{l}\text { Horiuchi et al., } \\
\text { 2008) }\end{array}$ & $\begin{array}{r}\text { Dome Fuji, } \\
\text { Antarctica }\end{array}$ & ${ }^{10} \mathrm{Be}$ & $\begin{array}{l}{ }^{10} \text { Be concen- } \\
\text { tration + flux }\end{array}$ & 700-1900 A.D. & $\sim 200-y r$ \\
\hline \multicolumn{6}{|c|}{ (1) The related 1500-yr scale (broadband $1000-2500$ yr) } \\
\hline $\begin{array}{l}\text { Bond et al., } \\
2001\end{array}$ & N. Atlantic & $\begin{array}{l}\text { Hermatite- } \\
\text { stained grains }\end{array}$ & $\begin{array}{l}\text { Ice-rafting } \\
\text { events }\end{array}$ & Holocene & "1500-yr" \\
\hline $\begin{array}{l}\text { Bianchi and } \\
\text { McCave, } \\
1999\end{array}$ & N. Atlantic & $\begin{array}{l}\text { Sortable silt } \\
\text { grain size } \\
(10-63 \mu \mathrm{m})\end{array}$ & $\begin{array}{l}\text { Iceland- } \\
\text { Scotland } \\
\text { Overflow } \\
\text { water }\end{array}$ & Holocene & $1500-y r$ \\
\hline $\begin{array}{l}\text { Farmer et al., } \\
2008\end{array}$ & N. Atlantic & $\begin{array}{c}\text { Mg/Ca ratios in } \\
\text { G. bulloides }\end{array}$ & SST & Last 12 kyr & $500-y r$ \\
\hline $\begin{array}{l}\text { Andrews et al., } \\
2009\end{array}$ & $\begin{array}{l}\text { Northern } \\
\text { Iceland } \\
\text { (multi-sites) }\end{array}$ & $\begin{array}{l}\text { X-ray } \\
\text { diffraction } \\
\text { analysis of } \\
<2 \mathrm{~mm} \\
\text { sediment } \\
\text { fraction }\end{array}$ & Drift ice & Last 12 kyr & $670-y r$ \\
\hline Hu et al., 2003 & $\begin{array}{l}\text { Arolik Lake } \\
\text { (SW Alaska) }\end{array}$ & Biogenic silica & $\begin{array}{l}\text { Aquatic } \\
\text { productivity }\end{array}$ & Last 15 kyr & $\begin{array}{l}\text { 1500-yr?, 950- } \\
y r, 195-y r\end{array}$ \\
\hline $\begin{array}{l}\text { Wollenburg et } \\
\text { al., } 2007\end{array}$ & $\begin{array}{l}\text { Arctic Ocean; } \\
\text { Eurasian } \\
\text { Basin }\end{array}$ & Fischer $\alpha$ & $\begin{array}{l}\text { Biodiversity of } \\
\text { benthic } \\
\text { foraminifera }\end{array}$ & Last 24 kyr & $\begin{array}{l}\text { 1.57-kyr, 0.76- } \\
\text { kyr (1.16-kyr, } \\
0.54-k y r \\
\text { Holocene) }\end{array}$ \\
\hline $\begin{array}{l}\text { Kim et al., } \\
2007\end{array}$ & Off NW Africa & $\begin{array}{l}\text { Alkenone, } \\
\delta{ }^{18} \mathrm{O}(\mathrm{G} . \\
\text { bulloides })\end{array}$ & $\begin{array}{l}\text { SST, upwelling } \\
\text { intensity, } \\
\text { subtropical } \\
\text { gyre }\end{array}$ & Last $10 \mathrm{kyr}$ & $2-3-k y r$ \\
\hline
\end{tabular}


Table A1. (Continued)

\begin{tabular}{|c|c|c|c|c|c|}
\hline Reference & Location & Data & Proxy & Time intervals & $\begin{array}{l}\text { Scales of vari- } \\
\text { ability detected }\end{array}$ \\
\hline $\begin{array}{l}\text { Moy et al., } \\
2002\end{array}$ & $\begin{array}{l}\text { Lake } \\
\text { Pallcacaocha } \\
\text { (S. Ecuador) }\end{array}$ & $\begin{array}{r}\text { Red-color } \\
\text { intensity }\end{array}$ & ENSO activity & Holocene & $\begin{array}{l}\text { 1500-yr, } \\
2000-y r\end{array}$ \\
\hline \multicolumn{6}{|c|}{ (2) North Atlantic + Greenland + Iceland } \\
\hline $\begin{array}{l}\text { Stuiver et al., } \\
\text { 1995; } \\
\text { Grootes and } \\
\text { Stuiver, } 1997\end{array}$ & GISP2 & $\delta{ }^{18} \mathrm{O}$ in ice & $\begin{array}{l}\text { Surface } \\
\text { temperature }\end{array}$ & Holocene part & $\begin{array}{r}210-y r, 70-y r \\
11-y r, 6.3-y r\end{array}$ \\
\hline $\begin{array}{l}\text { Yiou et al., } \\
1997\end{array}$ & GRIP & $\delta{ }^{18} \mathrm{O}$ in ice & $\begin{array}{l}\text { Surface } \\
\text { temperature }\end{array}$ & Holocene part & $\begin{array}{l}\text { 2-kyr, 180-yr, } \\
\text { 150-yr, } \\
120-y r\end{array}$ \\
\hline $\begin{array}{l}\text { Ram and Stolz, } \\
1999\end{array}$ & GISP2 & $\begin{array}{l}\text { Laser-light } \\
\text { scattering } \\
\text { from ice }\end{array}$ & $\begin{array}{l}\text { Atmospheric } \\
\text { dust }\end{array}$ & 92-14 kyr B.P. & $\begin{array}{c}91-y r, 197-y r+ \\
\text { distributions }\end{array}$ \\
\hline $\begin{array}{l}\text { Mayewski et } \\
\text { al., } 1997\end{array}$ & GISP2 & $\begin{array}{l}\text { Polar circula- } \\
\text { tion index } \\
\text { (glaciochemi- } \\
\text { cal data) }\end{array}$ & $\begin{array}{c}\text { Atmospheric } \\
\text { circulation }\end{array}$ & Last $110 \mathrm{kyr}$ & $1450-\mathrm{yr}$ \\
\hline $\begin{array}{l}\text { Fischer and } \\
\text { Mieding, } \\
2005\end{array}$ & $\begin{array}{l}\text { North } \\
\text { Greenland } \\
\text { Traverse } \\
\text { (NGT) ice } \\
\text { cores }\end{array}$ & $\begin{array}{l}\mathrm{Na}^{+} \\
\text {concentration }\end{array}$ & $\begin{array}{c}\text { Atmospheric } \\
\text { circulation }\end{array}$ & $\begin{array}{l}\text { 1066-1993 } \\
\text { A.D. }\end{array}$ & 10.4-yr, 62-yr \\
\hline $\begin{array}{l}\text { Andrews et al., } \\
2003\end{array}$ & North Iceland & $\begin{array}{c}\text { Sediment } \\
\text { magnetic } \\
\text { property, } \\
\text { grain size }\end{array}$ & $\begin{array}{l}\text { N. Atlantic } \\
\text { oceano- } \\
\text { graphic } \\
\text { conditions }\end{array}$ & Last $12 \mathrm{kyr}$ & $\begin{array}{l}\text { 200-yr, } \\
125-y r, 88-y r\end{array}$ \\
\hline $\begin{array}{l}\text { Moros et al., } \\
2006\end{array}$ & North Iceland & Quartz content & Drift ice & Last $12 \mathrm{kyr}$ & $\begin{array}{l}1.3-\mathrm{kyr}, \\
75-80-\mathrm{yr}\end{array}$ \\
\hline $\begin{array}{l}\text { Sicre et al., } \\
2008\end{array}$ & North Iceland & Alkenones & SST & Last $2000 \mathrm{yr}$ & $20-25 \mathrm{yr}$ \\
\hline \multicolumn{6}{|c|}{ (3) Northern Europe + Europe } \\
\hline $\begin{array}{l}\text { Allen et al., } \\
2007\end{array}$ & $\begin{array}{c}\text { Finnmark, } \\
\text { Norway }\end{array}$ & $\begin{array}{l}\text { Pollen + geo- } \\
\text { chemical data }\end{array}$ & $\begin{array}{l}\text { Vegetation } \\
\text { history }\end{array}$ & Holocene & $\begin{array}{l}\text { 1810-yr, 1650- } \\
\text { yr, 190-yr }\end{array}$ \\
\hline $\begin{array}{l}\text { Knutz et al., } \\
2007\end{array}$ & $\begin{array}{l}\text { NW Europe/ } \\
\text { British Ice } \\
\text { Sheet }\end{array}$ & $\begin{array}{l}\text { Ice-rafted } \\
\text { debris events }\end{array}$ & $\begin{array}{l}\text { Glacial margin/ } \\
\text { meltwater } \\
\text { surges/ } \\
\text { Atlantic MOC }\end{array}$ & 10-27 kyr B.P. & $180-220-y r$ \\
\hline $\begin{array}{l}\text { Haltia-Hovi et } \\
\text { al., } 2007\end{array}$ & $\begin{array}{l}\text { Lake } \\
\text { Lehmilampi, } \\
\text { E. Finland }\end{array}$ & Varve thickness & $\begin{array}{l}\text { Lake } \\
\text { sedimentation } \\
\text {-hydrology }\end{array}$ & Last 2000-yr & $\begin{array}{l}\text { Match } \Delta 14 C \\
\text { series }\end{array}$ \\
\hline $\begin{array}{l}\text { Swindles et al., } \\
2007\end{array}$ & $\begin{array}{l}\text { Fermanagh, N. } \\
\text { Ireland }\end{array}$ & $\begin{array}{l}\text { Peat humifica- } \\
\text { tion and plant } \\
\text { microfossil }\end{array}$ & Hydrology & $\begin{array}{l}2850 \mathrm{yr} \text { BC to } \\
1000 \text { A.D. }\end{array}$ & $265-\mathrm{yr}+$ others \\
\hline
\end{tabular}


Table A1. (Continued)

\begin{tabular}{|c|c|c|c|c|c|}
\hline Reference & Location & Data & Proxy & Time intervals & $\begin{array}{l}\text { Scales of vari- } \\
\text { ability detected }\end{array}$ \\
\hline $\begin{array}{l}\text { Chambers and } \\
\text { Blackford, } \\
2001\end{array}$ & $\begin{array}{l}\text { Four mire sites } \\
\text { in the UK }\end{array}$ & Wet-dry index & Hydrology & Last 2000-yr & $80-y r, 200-y r$ \\
\hline $\begin{array}{l}\text { Holzkamper et } \\
\text { al., } 2004\end{array}$ & $\begin{array}{l}\text { Spannagel } \\
\text { Cave, } \\
\text { Austrian Alps }\end{array}$ & $\begin{array}{l}\delta{ }^{18} \mathrm{O} \text { in } \\
\text { stalagmite }\end{array}$ & Hydrology & $\begin{array}{l}\text { 131-118 kyr } \\
\text { B.P. }\end{array}$ & $\begin{array}{l}197-y r, 109-y r, \\
21-y r\end{array}$ \\
\hline $\begin{array}{l}\text { Mangili et al., } \\
2007\end{array}$ & $\begin{array}{l}\text { Pianico } \\
\text { paleolake, } \\
\text { Southern Alps }\end{array}$ & $\begin{array}{l}\delta{ }^{18} \mathrm{O} \text { in calcite } \\
\text { varve }\end{array}$ & Hydrology & $\begin{array}{l}\text { 15,500 yr } \\
\text { during } \\
\text { Interglacial of } \\
400 \text { kyr B.P. }\end{array}$ & $\begin{array}{l}780-y r, 125 \text { to } \\
195-y r\end{array}$ \\
\hline \multicolumn{6}{|c|}{ (4) North America } \\
\hline $\begin{array}{l}\text { Yu and Ito, } \\
1999\end{array}$ & $\begin{array}{l}\text { Rice Lake, } \\
\text { North Dakota }\end{array}$ & $\begin{array}{l}\mathrm{Mg} / \mathrm{Ca} \text { ratio of } \\
\text { ostracode } \\
\text { shells }\end{array}$ & $\begin{array}{l}\text { Salinity/ } \\
\text { drought } \\
\text { frequency }\end{array}$ & Last 2100-yr & $\begin{array}{l}400-y r, 200-y r, \\
130-y r \\
100-y r\end{array}$ \\
\hline $\begin{array}{l}\text { Anderson, } \\
1992\end{array}$ & $\begin{array}{l}\text { Elk Lake, } \\
\text { Minnesota }\end{array}$ & Varve thickness & $\begin{array}{l}\text { Aeolian } \\
\text { activity/wind }\end{array}$ & $\begin{array}{l}2000-y r \text { in } 7.3 \\
\text { kyr-5.3 kyr B.P. }\end{array}$ & $\begin{array}{l}200-y r, 20 \text { to } \\
25-y r\end{array}$ \\
\hline Dean, 1997 & $\begin{array}{l}\text { Elk Lake, } \\
\text { Minnesota }\end{array}$ & $\begin{array}{l}\% \mathrm{Al}, \% \mathrm{Na} \text { in } \\
\text { varved lake } \\
\text { sediments }\end{array}$ & Aeolian activity & Last $1500-y r$ & $400-y r, 84-y r$ \\
\hline $\begin{array}{l}\text { Wang et al., } \\
2003\end{array}$ & $\begin{array}{l}\text { Fox Hill and } \\
\text { Keller Farm } \\
\text { loesses }\end{array}$ & $\begin{array}{c}\text { Lightness para- } \\
\text { meter, \% car- } \\
\text { bonate, \%Fe }\end{array}$ & $\begin{array}{l}\text { Persistent heat } \\
\text { and moisture } \\
\text { supply }\end{array}$ & 30-14 kyr B.P. & $\begin{array}{r}800 \text { to } 1000-y r \text {, } \\
450 \text { to } 550-y r \text {, } \\
350 \text { to } 390-y r\end{array}$ \\
\hline $\begin{array}{l}\text { Fortin and } \\
\text { Lamoureux, } \\
2009\end{array}$ & $\begin{array}{l}\text { Canadian } \\
\text { Arctic and } \\
\text { southeastern } \\
\text { boreal regions }\end{array}$ & $\begin{array}{l}\text { Lacustrine varve } \\
\text { and boreal } \\
\text { tree-ring width } \\
\text { series }\end{array}$ & $\begin{array}{l}\text { Hydrology + } \\
\text { AMO }\end{array}$ & $\begin{array}{l}\text { 1550-1986 } \\
\text { A.D. }\end{array}$ & $\begin{array}{l}64-y r, 20 \text { to } \\
40-y r\end{array}$ \\
\hline $\begin{array}{l}\text { Schimmelmann } \\
\text { et al., } 2003\end{array}$ & $\begin{array}{l}\text { Santa Barbara } \\
\text { basin }\end{array}$ & $\begin{array}{l}\text { Six major grey } \\
\text { flood deposits } \\
\text { in varved } \\
\text { sediments }\end{array}$ & $\begin{array}{l}\text { Floods and } \\
\text { droughts } \\
\text { cycle }\end{array}$ & Last 2000-yr & $200-y r$ \\
\hline $\begin{array}{l}\text { Douglas et al., } \\
2007\end{array}$ & $\begin{array}{l}\text { Gulf of } \\
\text { California }\end{array}$ & $\begin{array}{l}\text { Biogenic silica, } \\
\text { carbonate, } \\
\text { TOC }\end{array}$ & $\begin{array}{l}\text { Primary } \\
\text { productivity, } \\
\text { dissolution } \\
\text { cycles }\end{array}$ & Last $10000-y r$ & $\begin{array}{l}150-y r, 200-y r, \\
350-y r\end{array}$ \\
\hline $\begin{array}{l}\text { Patterson et al., } \\
2004 a, 2004 b\end{array}$ & $\begin{array}{l}\text { Vancouver } \\
\text { Island, } \\
\text { NE Pacific }\end{array}$ & $\begin{array}{c}\text { Sediment color } \\
\text { (X-ray images), } \\
\text { anchovy }+ \\
\text { herring scales }\end{array}$ & $\begin{array}{l}\text { Hydrology, } \\
\text { ocean } \\
\text { biological } \\
\text { productivity }\end{array}$ & $\begin{array}{l}1400-4700 \mathrm{yr} \\
\text { B.P. }\end{array}$ & $\begin{array}{l}\sim 75 \text { to } 90-y r \\
\text { among others }\end{array}$ \\
\hline $\begin{array}{l}\text { Springer et al., } \\
2008\end{array}$ & West Virginia & $\begin{array}{c}\text { Sr/Ca ratios and } \\
\delta{ }^{13} \mathrm{C} \text { values } \\
\text { in stalagmite }\end{array}$ & $\begin{array}{l}\text { Hydrology, } \\
\text { droughts }\end{array}$ & Last 7000-yr & $\begin{array}{l}715-y r, 550-y r, \\
455-y r \\
210-y r\end{array}$ \\
\hline $\begin{array}{l}\text { Hubeny et al., } \\
2006\end{array}$ & $\begin{array}{l}\text { Pettaquamscutt } \\
\text { River Estuary, } \\
\text { Rhode Island }\end{array}$ & $\begin{array}{l}\text { Fossil pigment } \\
\text { Bchle (Bacte- } \\
\text { riochloro- } \\
\text { phyll e) }\end{array}$ & $\begin{array}{l}\text { Modes of large- } \\
\text { scale climate } \\
\text { variations, } \\
\mathrm{NAO}+\mathrm{AMO}\end{array}$ & $\begin{array}{l}\text { 1024-2004 } \\
\text { A.D. }\end{array}$ & $\begin{array}{c}95.9-y r, 38.5- \\
y r, 11.6-y r \\
8-y r, 5.5-y r\end{array}$ \\
\hline
\end{tabular}


Table A1. (Continued)

\begin{tabular}{|c|c|c|c|c|c|}
\hline Reference & Location & Data & Proxy & Time intervals & $\begin{array}{l}\text { Scales of vari- } \\
\text { ability detected }\end{array}$ \\
\hline $\begin{array}{l}\text { Asmeron et al., } \\
2007\end{array}$ & $\begin{array}{l}\text { Southwestern } \\
\text { U.S. }\end{array}$ & $\begin{array}{l}\delta{ }^{18} \mathrm{O} \text { values in } \\
\text { stalagmite }\end{array}$ & $\begin{array}{l}\text { Hydrology, } \\
\text { circulation, } \\
\text { droughts }\end{array}$ & Last $12,000-y r$ & $\begin{array}{l}\text { 1533-yr, 444- } \\
\text { yr, 146-yr, } \\
88-y r\end{array}$ \\
\hline $\begin{array}{l}\text { McCabe et al., } \\
2008\end{array}$ & $\begin{array}{l}\text { Yellowstone } \\
\text { National Park }\end{array}$ & $\begin{array}{l}\text { Tree-ring and } \\
\text { instrumental } \\
\text { data }\end{array}$ & $\begin{array}{l}\text { Hydrology, } \\
\text { precipitation, } \\
\text { drought }\end{array}$ & Last $820-y r$ & $\sim 60-y \mathrm{r}, \sim 20-\mathrm{yr}$ \\
\hline $\begin{array}{l}\text { Wilson et al., } \\
2007\end{array}$ & Gulf of Alaska & Tree-rind width & Temperature & Last $1300-y r$ & $\begin{array}{l}18.7-y r, 50.4- \\
\text { yr, } 90-y r \\
38-y r, 24-y r \\
14 \text { to } 15-y r \\
9 \text { to } 11-y r\end{array}$ \\
\hline $\begin{array}{l}\text { Wiles et al., } \\
2009\end{array}$ & $\begin{array}{l}\text { Gulf of Alaska, } \\
\text { Lake Erie }\end{array}$ & $\begin{array}{l}\text { Tree-ring and } \\
\text { lake water } \\
\text { level }\end{array}$ & $\begin{array}{l}\text { Hydrology, } \\
\text { Lake Erie } \\
\text { level }\end{array}$ & Last 265-yr & $\begin{array}{l}116-\mathrm{yr}, 76-\mathrm{yr}, \\
28 \text { to } 20-\mathrm{yr}, \\
17 \text { to } 14-\mathrm{yr}, \\
12-\mathrm{yr}, 11.2-\mathrm{yr}\end{array}$ \\
\hline \multicolumn{6}{|c|}{ (5) Gulf of Mexico (GOM) + Caribbean, Cariaco Basin } \\
\hline $\begin{array}{l}\text { Poore et al., } \\
2004\end{array}$ & $\begin{array}{l}\text { Pigmy basin, } \\
\text { northern } \\
\text { GOM }\end{array}$ & $\begin{array}{l}\text { Abundance of } \\
\text { G. sacculifer }\end{array}$ & $\begin{array}{c}\text { Atlantic ITCZ } \\
\text { movements }\end{array}$ & Last 5000-yr & $512-y r, 180-y r$ \\
\hline $\begin{array}{l}\text { Poore et al., } \\
2004\end{array}$ & $\begin{array}{r}\text { Core RC12-10, } \\
\text { western GOM }\end{array}$ & $\begin{array}{l}\text { Abundance of } \\
\text { G. sacculifer }\end{array}$ & $\begin{array}{c}\text { Atlantic ITCZ } \\
\text { movements }\end{array}$ & $\begin{array}{l}7.4 \text { to } 2.8 \mathrm{kyr} \\
\text { B.P. }\end{array}$ & $550-y r, 210-y r$ \\
\hline $\begin{array}{l}\text { Hodell et al., } \\
2001 \\
\text { (Yucatan } \\
\text { Peninsula) }\end{array}$ & $\begin{array}{l}\text { Lakes Chichan- } \\
\text { canab and } \\
\text { Punta Laguna }\end{array}$ & $\begin{array}{l}\text { Bulk density } \\
\text { and } \delta{ }^{18} \mathrm{O}\end{array}$ & $\begin{array}{l}\text { Hydrology, } \\
\text { drought } \\
\text { cycles }\end{array}$ & Last 2600-yr & $208-y r$ \\
\hline $\begin{array}{l}\text { Nyberg et al., } \\
2001,2002\end{array}$ & $\begin{array}{l}\text { SW Puerto } \\
\text { Rico }\end{array}$ & $\begin{array}{l}\text { Three mineral } \\
\text { magnetic } \\
\text { parameters, } \\
\delta^{18} \mathrm{O} \text { of } \\
\text { planktonic } \\
\text { foraminifera }\end{array}$ & $\begin{array}{l}\text { Hydrology, } \\
\text { drought } \\
\text { cycles, SST, } \\
\text { SSS }\end{array}$ & Last 2000-yr & $217-y r$ \\
\hline $\begin{array}{l}\text { Black et al., } \\
2004\end{array}$ & Cariaco Basin & $\begin{array}{l}\delta^{18} \mathrm{O} \text { in } \\
\text { planktic } \\
\text { G. bulloides }\end{array}$ & $\begin{array}{l}\text { SST and ITCZ- } \\
\text { precip-related } \\
\text { salinity }\end{array}$ & Last 300-yr & $\begin{array}{l}159-y r, 24-y r \\
10.9-y r\end{array}$ \\
\hline $\begin{array}{l}\text { Lund and } \\
\text { Curry, } 2004\end{array}$ & $\begin{array}{l}\text { South of Dry } \\
\text { Tortugas }\end{array}$ & $\begin{array}{l}\text { Planktonic } \\
\text { foraminiferal } \\
\delta{ }^{18} \mathrm{O}\end{array}$ & Florida current & Last 5200-yr & $\begin{array}{c}360-y r, 190-y r \\
130-y r, 100- \\
\text { yr, and } 80-y r\end{array}$ \\
\hline \multicolumn{6}{|c|}{ (6) Equatorial + Tropical Africa } \\
\hline $\begin{array}{l}\text { Russell and } \\
\text { Johnson, } \\
\text { 2005a }\end{array}$ & $\begin{array}{l}\text { Lake Edward, } \\
\text { Congo }\end{array}$ & $\begin{array}{l}\% \text { Mg in calcite } \\
\text { of lake } \\
\text { sediment }\end{array}$ & $\begin{array}{l}\text { Salinity/water } \\
\text { balance/ITCZ } \\
\text { movements }\end{array}$ & Last 5400-yr & $1500-y r$ \\
\hline $\begin{array}{l}\text { Russell and } \\
\text { Johnson, } \\
2005 b\end{array}$ & $\begin{array}{l}\text { Lake Edward, } \\
\text { Congo }\end{array}$ & $\begin{array}{l}\text { \% biogenic } \\
\text { silica of lake } \\
\text { sediment }\end{array}$ & $\begin{array}{c}\text { Salinity/water } \\
\text { balance/ITCZ } \\
\text { movements }\end{array}$ & Last 5400-yr & $\begin{array}{l}725-y r, 125-y r \\
63-72-y r \text {, and } \\
\text { others }\end{array}$ \\
\hline
\end{tabular}


Table A1. (Continued)

\begin{tabular}{|c|c|c|c|c|c|}
\hline Reference & Location & Data & Proxy & Time intervals & $\begin{array}{l}\text { Scales of vari- } \\
\text { ability detected }\end{array}$ \\
\hline $\begin{array}{l}\text { Stager et al., } \\
1997\end{array}$ & $\begin{array}{l}\text { Lake Victoria, } \\
\text { East Africa }\end{array}$ & $\begin{array}{l}\text { Abundance of } \\
\text { diatom } \\
\text { species in } \\
\text { lake sediment }\end{array}$ & $\begin{array}{l}\text { Aridity/lake } \\
\text { levels }\end{array}$ & Last $13 \mathrm{kyr}$ & $\begin{array}{l}\text { 2350- to 2550- } \\
\text { yr, 1400-yr, } \\
\text { and others }\end{array}$ \\
\hline $\begin{array}{l}\text { Kuhlmann et } \\
\text { al., } 2004\end{array}$ & Off NW Africa & $\begin{array}{l}\text { Potassium } \\
\text { intensity in } \\
\text { sediment core }\end{array}$ & $\begin{array}{l}\text { Proxy of terrig- } \\
\text { enous supply } \\
\text { to marine sed- } \\
\text { iment }\end{array}$ & Last $9 \mathrm{kyr}$ & $900-y r$ \\
\hline $\begin{array}{l}\text { Hanebuth and } \\
\text { Henrich, } 2009\end{array}$ & $\begin{array}{c}\text { Off NW Africa } \\
\text { (Mauritania) }\end{array}$ & $\begin{array}{l}\text { Dust supply/ } \\
\text { accumulation }\end{array}$ & $\begin{array}{r}\text { Turbidite } \\
\text { activity }\end{array}$ & Last $11 \mathrm{kyr}$ & $900 \pm 150-y r$ \\
\hline \multicolumn{6}{|c|}{ (7) Indian Monsoon } \\
\hline $\begin{array}{l}\text { Neff et al., } \\
2001\end{array}$ & $\begin{array}{l}\text { Hoti Cave, } \\
\text { northern } \\
\text { Oman }\end{array}$ & $\begin{array}{c}\delta{ }^{18} \mathrm{O} \text { in dated } \\
\text { speleothems }\end{array}$ & $\begin{array}{l}\text { Regional } \\
\text { precipitation/ } \\
\text { Indian } \\
\text { monsoon }\end{array}$ & 9-6 kyr B.P. & $\begin{array}{l}\text { 1018-yr, 226-yr, } \\
\text { 28-yr, 10.7-yr, } \\
9-y r \text { (untuned); } \\
\text { 205-yr, 87-yr } \\
\text { (tuned) }\end{array}$ \\
\hline $\begin{array}{l}\text { Agnihotri et al., } \\
2002\end{array}$ & $\begin{array}{l}\text { Northeastern } \\
\text { Arabian Sea }\end{array}$ & $\begin{array}{l}\text { Biogenic } \\
\text { proxies }\left(\mathrm{C}_{\text {org }}\right. \\
\text { and } \mathrm{N}) \text { and } \\
\% \mathrm{Al}\end{array}$ & $\begin{array}{l}\text { Intensity of } \\
\text { Indian } \\
\text { monsoon }\end{array}$ & Last $1200-y r$ & $\begin{array}{c}200 \pm 20-y r \\
105 \pm 15-y r \\
60 \pm 10-y r\end{array}$ \\
\hline $\begin{array}{l}\text { Gupta et al., } \\
2005\end{array}$ & $\begin{array}{l}\text { Northwestern } \\
\text { Arabian Sea, } \\
\text { off Oman }\end{array}$ & $\begin{array}{l}\text { Abundance of } \\
\text { planktic } \\
\text { G. bulloides }\end{array}$ & $\begin{array}{l}\text { Indian } \\
\text { monsoon }\end{array}$ & Last 11.1-kyr & $\begin{array}{c}\text { 1550-yr, 152-yr, } \\
137-y r, 114- \\
\text { yr, 101-yr, 89, } \\
83 \text {, and 79-yr }\end{array}$ \\
\hline $\begin{array}{l}\text { Fleitmann et } \\
\text { al., } 2003\end{array}$ & $\begin{array}{l}\text { Qunf Cave, } \\
\text { southern } \\
\text { Oman }\end{array}$ & $\begin{array}{c}\delta{ }^{18} \mathrm{O} \text { in dated } \\
\text { speleothems }\end{array}$ & $\begin{array}{l}\text { Regional } \\
\text { precipitation/ } \\
\text { Indian } \\
\text { monsoon }\end{array}$ & $\begin{array}{l}\text { Last } 11 \text { kyr } \\
\text { (with some } \\
\text { data gaps) }\end{array}$ & $\begin{array}{l}\text { 220-yr, 140-yr, } \\
107-y r, 11- \\
\text { and 10-yr } \\
\text { (untuned) }\end{array}$ \\
\hline $\begin{array}{l}\text { Burns et al., } \\
2002\end{array}$ & $\begin{array}{l}\text { Salalah region, } \\
\text { Oman }\end{array}$ & $\begin{array}{l}\text { Layer } \\
\text { thickness, } \\
\delta^{13} \mathrm{C} \text { and } \\
\delta^{18} \mathrm{O}\end{array}$ & $\begin{array}{l}\text { Regional } \\
\text { precipitation/ } \\
\text { monsoon } \\
\text { rainfall }\end{array}$ & Last 780-yr & $\begin{array}{l}204-y r, 97-y r, \\
19.8-y r, 16.1- \\
y r, 12.8-y r, \\
\text { and } 6.6-y r \text { (in } \\
\delta{ }^{18} \text { O spectra) }\end{array}$ \\
\hline \multicolumn{6}{|c|}{ (8) East Asia + East Asian monsoon } \\
\hline $\begin{array}{l}\text { Wang et al., } \\
2005\end{array}$ & $\begin{array}{l}\text { Dongge Cave, } \\
\text { southern } \\
\text { China }\end{array}$ & $\begin{array}{l}\delta{ }^{18} \mathrm{O} \text { in } \\
\text { absolutely } \\
\text { dated } \\
\text { stalagmite }\end{array}$ & $\begin{array}{l}\text { Regional } \\
\text { precipitation/ } \\
\text { strength of } \\
\text { Asian } \\
\text { monsoon }\end{array}$ & Last 9000-yr & $\begin{array}{l}\text { 558-yr, 206-yr, } \\
159-y \mathrm{r}\end{array}$ \\
\hline $\begin{array}{l}\text { Cosford et al., } \\
2008\end{array}$ & $\begin{array}{l}\text { LianHua Cave, } \\
\text { Hunan, China }\end{array}$ & $\begin{array}{l}\delta^{18} \mathrm{O} \text { in } \\
\text { absolutely } \\
\text { dated } \\
\text { stalagmite }\end{array}$ & $\begin{array}{l}\text { Regional } \\
\text { precipitation/ } \\
\text { strength of } \\
\text { Asian } \\
\text { monsoon }\end{array}$ & Last 7000-yr & $\begin{array}{l}220-y r, 83-y r, \\
50-y r\end{array}$ \\
\hline
\end{tabular}


Table A1. (Continued)

\begin{tabular}{|c|c|c|c|c|c|}
\hline Reference & Location & Data & Proxy & Time intervals & $\begin{array}{l}\text { Scales of vari- } \\
\text { ability detected }\end{array}$ \\
\hline $\begin{array}{l}\text { Zhang et al., } \\
2008\end{array}$ & $\begin{array}{l}\text { WanXiang } \\
\text { Cave, Gansu, } \\
\text { China }\end{array}$ & $\begin{array}{l}\delta{ }^{18} \mathrm{O} \text { in } \\
\text { absolutely } \\
\text { dated } \\
\text { stalagmite }\end{array}$ & $\begin{array}{l}\text { Regional } \\
\text { precipitation/ } \\
\text { strength of } \\
\text { Asian } \\
\text { monsoon }\end{array}$ & Last $1810-y r$ & $\begin{array}{c}170-y r, 10.5-y r \\
6.4-y r, 5.5-y r\end{array}$ \\
\hline $\begin{array}{l}\text { Zhong et al., } \\
2007\end{array}$ & $\begin{array}{l}\text { S. Tarim Basin, } \\
\text { Xinjian, NW } \\
\text { China }\end{array}$ & $\begin{array}{l}\text { Mean grain } \\
\text { size and other } \\
\text { measures }\end{array}$ & $\begin{array}{l}\text { Hydrology/ } \\
\text { wet-dry } \\
\text { cycles }\end{array}$ & Last 4000-yr & $\begin{array}{l}\text { 200-yr, 120-yr, } \\
90-y r, \text { and } \\
\text { others }\end{array}$ \\
\hline Lim et al., 2005 & $\begin{array}{l}\text { Cheju Island, } \\
\text { Korea }\end{array}$ & $\begin{array}{l}\text { Eolian quartz } \\
\text { flux }\end{array}$ & $\begin{array}{l}\text { Hydrology/ } \\
\text { Asian dust }\end{array}$ & Last 6500-yr & $\begin{array}{l}\text { 1137-yr, 739- } \\
\text { yr, 214-yr, } \\
162,137, \\
127,111-y r\end{array}$ \\
\hline Ji et al., 2005 & $\begin{array}{l}\text { Qinghai Lake, } \\
\text { Qinghai- } \\
\text { Tibetan } \\
\text { Plateau }\end{array}$ & $\begin{array}{l}\text { Visible reflec- } \\
\text { tance (redness } \\
\text { record/iron } \\
\text { oxide content) }\end{array}$ & $\begin{array}{l}\text { Hydrology/ } \\
\text { Asian and } \\
\text { Indian } \\
\text { monsoon }\end{array}$ & Last $18 \mathrm{kyr}$ & $\begin{array}{l}293-y r, 200-y r, \\
163-y r, 123- \\
y r\end{array}$ \\
\hline Ji et al., 2009 & $\begin{array}{l}\text { Qinghai Lake, } \\
\text { Qinghai- } \\
\text { Tibetan } \\
\text { Plateau }\end{array}$ & $\begin{array}{l}\text { Abudance of } \\
\text { bacteriophae } \\
\text { ophytina }\end{array}$ & $\begin{array}{l}\text { Productivity of } \\
\text { anoxygenic } \\
\text { phototrophic } \\
\text { bacteria (APB) }\end{array}$ & Last $18 \mathrm{kyr}$ & $\begin{array}{l}\text { Durations of } \\
\text { APB peaks: } \\
60 \text { - to } 70-y \mathrm{r}, \\
90 \text { - to } 100-\mathrm{yr} \text {, } \\
\text { 130- to } 140-\mathrm{yr} \text {, } \\
\text { 160- to } 170-\mathrm{yr} \text {, } \\
200 \text { - to } 210-\mathrm{yr}\end{array}$ \\
\hline Xu et al., 2006 & $\begin{array}{l}\text { Hongyuan, } \\
\text { eastern } \\
\text { Qinghai- } \\
\text { Tibetan } \\
\text { Plateau }\end{array}$ & $\begin{array}{l}\delta{ }^{18} \mathrm{O} \text { in peat } \\
\text { cellulose }\end{array}$ & Temperatures & Last 6000-yr & Quasi 100-yr \\
\hline Tan et al., 2003 & $\begin{array}{l}\text { Shihua Cave, } \\
\text { Beijing }\end{array}$ & $\begin{array}{l}\text { Staglamite } \\
\text { growth layers }\end{array}$ & Temperatures & Last 2650-yr & $206-y r, 325-y r$ \\
\hline $\begin{array}{l}\text { Hong et al., } \\
\text { 2000, } 2001\end{array}$ & $\begin{array}{l}\text { Jinchuan, } \\
\text { northeastern } \\
\text { China }\end{array}$ & $\begin{array}{l}\delta{ }^{18} \mathrm{O} \text { and } \\
\delta{ }^{13} \mathrm{C} \text { in peat } \\
\text { cellulose }\end{array}$ & $\begin{array}{l}\text { Temperature } \\
\text { and } \\
\text { hydrology }\end{array}$ & Last 6000-yr & $\begin{array}{l}207 \text { (205)-yr } \\
\text { and other cen- } \\
\text { tennial to mil- } \\
\text { lennial scales }\end{array}$ \\
\hline $\begin{array}{l}\text { Wei et al., } \\
2008\end{array}$ & Beijing, China & Instrumental & $\begin{array}{l}\text { Summer } \\
\text { rainfall }\end{array}$ & $\begin{array}{l}\text { 1724-2005 } \\
\text { A.D. }\end{array}$ & $\begin{array}{l}70-y r, 31-y r \\
20-y r\end{array}$ \\
\hline $\begin{array}{l}\text { Shen et al., } \\
2006\end{array}$ & Eastern China & $\begin{array}{l}\text { Documentary } \\
\text { records- } \\
\text { Drought/ } \\
\text { flood Index }\end{array}$ & $\begin{array}{l}\text { Summer } \\
\text { rainfall/PDO }\end{array}$ & $\begin{array}{l}\text { 1470-2000 } \\
\text { A.D. }\end{array}$ & $\begin{array}{l}75-\text { to } 115-y r \\
50-\text { to } 70-y r\end{array}$ \\
\hline $\begin{array}{l}\text { Chu et al., } \\
2008\end{array}$ & $\begin{array}{l}\text { Eastern China/ } \\
\text { Korea }\end{array}$ & $\begin{array}{l}\text { Documentary } \\
\text { records }\end{array}$ & Snow events & Last 2000 years & $281-y r, 103-y r$ \\
\hline $\begin{array}{l}\text { Raspopov et } \\
\text { al., } 2008\end{array}$ & $\begin{array}{l}\text { Tienshan } \\
\text { Mountains } \\
\text { and Tibetan } \\
\text { Plateau }\end{array}$ & Tree-ring width & $\begin{array}{l}\text { Summer } \\
\text { temperature/ } \\
\text { precipitation }\end{array}$ & 600-2000 A.D. & $\sim 200-y r$ \\
\hline
\end{tabular}


Table A1. (Continued)

\begin{tabular}{|c|c|c|c|c|c|}
\hline Reference & Location & Data & Proxy & Time intervals & $\begin{array}{l}\text { Scales of vari- } \\
\text { ability detected }\end{array}$ \\
\hline \multicolumn{6}{|c|}{ (9) Other regions and proxies (examples only) } \\
\hline $\begin{array}{l}\text { Eichler et al., } \\
2009\end{array}$ & $\begin{array}{l}\text { Belukha } \\
\text { Glacier, } \\
\text { Siberian Altai } \\
\text { Mountain } \\
\text { region }\end{array}$ & $\begin{array}{l}\delta{ }^{18} \mathrm{O} \text { from } \\
\text { glacier ice } \\
\text { core }\end{array}$ & $\begin{array}{l}\text { Temperature } \\
\text { (March- } \\
\text { November) }\end{array}$ & $\begin{array}{l}\text { 1250-2000 } \\
\text { A.D. }\end{array}$ & $\begin{array}{l}205-y r, 86-y r \\
10.8-y r\end{array}$ \\
\hline $\begin{array}{l}\text { Sano et al., } \\
2009\end{array}$ & $\begin{array}{l}\text { Northern } \\
\text { Vietnam (Mu } \\
\text { Cang Chai) }\end{array}$ & Tree-ring index & $\begin{array}{l}\text { Hydrology, } \\
\text { droughts }\end{array}$ & $\begin{array}{l}\text { 1470-2004 } \\
\text { A.D. }\end{array}$ & $\begin{array}{l}\text { 54- to 79-yr, } \\
3.2-y r, 2.5-y r, \\
2.0-y r\end{array}$ \\
\hline $\begin{array}{l}\text { Ruzmaikin et } \\
\text { al., } 2006\end{array}$ & Nile River & Water level & Hydrology & 622-1470 A.D. & $88-y r, 260-y r$ \\
\hline $\begin{array}{l}\text { van Beynen et } \\
\text { al., } 2008\end{array}$ & $\begin{array}{l}\text { Briars Cave, } \\
\text { central } \\
\text { Florida }\end{array}$ & $\begin{array}{c}\delta{ }^{13} \mathrm{C}+\mathrm{Sr} \text { in } \\
\text { stalagmite }\end{array}$ & $\begin{array}{l}\text { Soil } \\
\text { productivity/ } \\
\text { precipitation }\end{array}$ & Last 4000-yr & $\begin{array}{l}\text { 170- to } 180-y r \\
\text { and other } \\
\text { scales }\end{array}$ \\
\hline $\begin{array}{l}\text { Dima et al., } \\
2005\end{array}$ & $\begin{array}{l}\text { Rarotonga } \\
\text { coral, Cook } \\
\text { Islands, South } \\
\text { Pacific }\end{array}$ & $\mathrm{Sr} / \mathrm{Ca}$ in coral & SST & $\begin{array}{l}\text { 1727-1996 } \\
\text { A.D. }\end{array}$ & $\sim 80-\mathrm{yr}, \sim 25-\mathrm{yr}$ \\
\hline $\begin{array}{l}\text { Gedalof et al., } \\
2002\end{array}$ & $\begin{array}{l}\text { Pacific Ocean } \\
\text { (north to } \\
\text { south) }\end{array}$ & $\begin{array}{l}\text { PC1 from } \\
\text { Multiproxy- } \\
\text { tree rings }+ \\
\text { corals }\end{array}$ & $\begin{array}{l}\text { PDO (Oct- } \\
\text { Mar) proxy }\end{array}$ & $\begin{array}{l}\text { 1840-1990 } \\
\text { A.D. }\end{array}$ & $\begin{array}{l}\sim 85-\mathrm{yr}, \sim 23-\mathrm{yr}, \\
\sim 20-\mathrm{yr}\end{array}$ \\
\hline $\begin{array}{l}\text { Agnihotri et al., } \\
2008\end{array}$ & Peru margin & $\mathrm{Ti}$ & $\begin{array}{l}\text { Ocean } \\
\text { productivity }\end{array}$ & Last 2000-yr & $\begin{array}{l}250-y r, 83-y r \\
22-\text { to } 24-y r \\
11-\text { to } 9.4-y r\end{array}$ \\
\hline \multicolumn{6}{|c|}{ (10) Southern Ocean and Antarctica } \\
\hline $\begin{array}{l}\text { Lamy et al., } \\
2001\end{array}$ & $\begin{array}{l}\text { Core GeoB } \\
\text { 3313-1, } \\
\text { southern } \\
\text { Chile }\end{array}$ & Iron content & $\begin{array}{l}\text { Regional } \\
\text { precipitation/ } \\
\text { variability + } \\
\text { shift of } \\
\text { southern } \\
\text { westerlies }\end{array}$ & Last 7700-yr & $\begin{array}{l}1750 \text { yr + } \\
1340-y r \text { (ca. } \\
1500-y r \\
\text { band), } 950-y r \\
+820-y r \text { (ca. } \\
900-y r \text { band) }\end{array}$ \\
\hline $\begin{array}{l}\text { Nielsen et al., } \\
2004\end{array}$ & $\begin{array}{l}\text { Site TN057-17, } \\
\text { Polar Front, } \\
\text { East Atlantic } \\
\text { Southern } \\
\text { Ocean }\end{array}$ & $\begin{array}{c}\text { Relative diatom } \\
\text { abundances }\end{array}$ & $\begin{array}{l}\text { Summer SST + } \\
\text { sea ice } \\
\text { presence }\end{array}$ & Last $12.5-\mathrm{kyr}$ & $\begin{array}{l}\text { 1220-yr, 1070- } \\
y r, 400-y r \\
150-y r\end{array}$ \\
\hline $\begin{array}{l}\text { Delmonte et } \\
\text { al., } 2004\end{array}$ & $\begin{array}{l}\text { Vostok and } \\
\text { Dome C, East } \\
\text { Antactica }\end{array}$ & $\begin{array}{l}\% \text { coarse } \\
\text { particles }\end{array}$ & $\begin{array}{l}\text { Hydrology/ } \\
\text { atmospheric } \\
\text { circulation } \\
\text { (dipolar } \\
\text { oscillations) }\end{array}$ & $\begin{array}{l}\text { 9.8- to } 3.5 \mathrm{kyr} \\
\text { B.P. }\end{array}$ & $\begin{array}{l}\text { 180- to } 210-y r, \\
130-\text { to } 150- \\
\text { yr (Dome C); } \\
150-\text { to } 230- \\
\text { yr, 120- to } \\
140-y r \\
\text { (Vostok) }\end{array}$ \\
\hline
\end{tabular}


Table A1. (Continued)

\begin{tabular}{|c|c|c|c|c|c|}
\hline Reference & Location & Data & Proxy & Time intervals & $\begin{array}{l}\text { Scales of vari- } \\
\text { ability detected }\end{array}$ \\
\hline $\begin{array}{l}\text { Leventer et al., } \\
1996\end{array}$ & $\begin{array}{l}\text { Palmer deep } \\
\text { basins/ } \\
\text { Antarctic } \\
\text { Peninsula }\end{array}$ & $\begin{array}{l}\text { Multi-variables } \\
\text { (including } \\
\text { magnetic } \\
\text { susceptibility, } \\
\text { diatoms) }\end{array}$ & Temperatures & Last 6000-yr & $\begin{array}{l}\text { quasi } 200-y r \\
\text { and } 2500-y r \\
\text { cycles }\end{array}$ \\
\hline $\begin{array}{l}\text { Masson- } \\
\text { Delmotte et } \\
\text { al., } 2004\end{array}$ & $\begin{array}{l}\text { EPICA Dome } \\
\text { C, East } \\
\text { Antarctica }\end{array}$ & $\delta \mathrm{D}$ in ice & $\begin{array}{l}\text { Site } \\
\text { temperature }\end{array}$ & Last 5000-yr & $\begin{array}{l}833-y r, 220-y r \\
\text { and } 60-y r\end{array}$ \\
\hline $\begin{array}{l}\text { Watanabe et } \\
\text { al., } 1998, \\
1999\end{array}$ & $\begin{array}{l}\text { Site S25, } \\
\text { Mizuho } \\
\text { Plateau/ } \\
\text { coastal East } \\
\text { Antarctica }\end{array}$ & $\begin{array}{l}\mathrm{H}_{2} \mathrm{O}_{2} \\
\text { nss } \mathrm{SO}_{4}{ }^{2-} \\
\mathrm{NO}_{3}^{-}\end{array}$ & $\begin{array}{l}\text { Atmospheric } \\
\text { circulation }\end{array}$ & $\begin{array}{l}\text { 1890-1980 } \\
\text { A.D. }\end{array}$ & $11-y r$ \\
\hline $\begin{array}{l}\text { Goodwin et al., } \\
2004\end{array}$ & $\begin{array}{l}\text { Law Dome/East } \\
\text { Antarctica }\end{array}$ & $\begin{array}{l}\text { Early winter } \\
\text { sea salt }(\mathrm{Na}) \\
\text { aerosol } \\
\text { concentration }\end{array}$ & $\begin{array}{l}\text { Mid-latitude } \\
\text { winter } \\
\text { atmospheric } \\
\text { variability }\end{array}$ & $\begin{array}{l}\text { 1301-1995 } \\
\text { A.D. }\end{array}$ & $\begin{array}{l}10.5-y r, 3.9+ \\
3.2-y r, 2.33+ \\
2.18-y r\end{array}$ \\
\hline $\begin{array}{l}\text { McConnell et } \\
\text { al., } 2007\end{array}$ & $\begin{array}{l}\text { James Ross } \\
\text { Island, } \\
\text { Antarctic } \\
\text { Peninsula }\end{array}$ & $\begin{array}{l}\text { Aluminum } \\
\text { concentration } \\
\text { and flux }\end{array}$ & $\begin{array}{l}\text { Atmospheric } \\
\text { circulation, } \\
\text { aridity of dust } \\
\text { source } \\
\text { regions }\end{array}$ & $\begin{array}{l}\text { 1832-1991 } \\
\text { A.D. }\end{array}$ & $\begin{array}{l}\text { 10.7- to } 13.2- \\
\mathrm{yr}, 21.3-\mathrm{yr}, \\
1.52-\mathrm{yr}, 1.8- \\
\mathrm{yr}, 3.55-\text { to } \\
3.71-\mathrm{yr}, 4.73- \\
\mathrm{yr}\end{array}$ \\
\hline
\end{tabular}

List of abbreviated references to Table A1:

Agnihotri et al. (2002) EPSL, Vol. 198, 521-527.

Agnihotri et al. (2008) GGG, Vol. 9, doi:10.1029/2007GC001744.

Allen et al. (2007) QSR, Vol. 26, 1432-1453.

Anderson (1992) Nature, Vol. 358, 51-53.

Andrews et al. (2003) EPSL, Vol. 210, 453-465.

Andrews et al. (2009) Holocene, Vol. 19, 71-77.

Asmeron et al. (2007) Geology, Vol. 35, 1-4.

Bianchi and McCave (1999) Nature, Vol. 397, 515-517.

Black et al. (2004) Paleoceanography, Vol. 19, doi:10.1029/2003PA000982.

Bond et al. (2001) Science, Vol. 294, 2130-2136.

Burns et al. (2002) JGR, Vol. 107, doi:10.1029/2001JD001281.

Chambers and Blackford (2001) JQS, Vol. 16, 329-338.

Chu et al. (2008) GRL, Vol. 35, doi:10.1029/2008GL034475.

Cosford et al. (2008) EPSL, Vol. 275, 296-307.

Dean (1997) Geology, Vol. 25, 331-334.

Delmonte et al. (2004) Climate Dynamics, Vol. 23, 427-438.

Dima et al. (2005) Climate Dynamics, Vol. 25, 329-336.

Douglas et al. (2007) QSR, Vol. 26, 115-129.

Eichler et al. (2009) GRL, Vol. 36, doi:10.1029/2008GL035930.

Farmer et al. (2008) G3, Vol. 9, doi:10.1029/2008GC002199. 
Fischer and Mieding (2005) Climate Dynamics, Vol. 25, 65-74.

Fleitmann et al. (2003) Science, Vol. 300, 1737-1739.

Fortin and Lamoureux (2009) Climate Dynamics, in press, doi:10.1007/s00382-008-0422-6.

Gedalof et al. (2002) GRL, Vol. 29, doi:10.1029/2002GL015824.

Goodwin et al. (2004) Climate Dynamics, Vol. 22, 783-794.

Grootes and Stuiver (1997) JGR, Vol. 102, 26455-26470.

Gupta et al. (2005) GRL, Vol. 32, doi:10.1029/2005GL022685.

Haltia-Hovi et al. (2007) QSR, Vol. 26, 678-689.

Hanebuth and Henrich (2009) QSR, in press, doi:10.1016/j.quascirev.2008.09.024.

Hansen and Lebedeff (1987) JGR, Vol. 92, 13345-13372.

Hodell et al. (2001) Science, Vol. 292, 1367-1370.

Holzkamper et al. (2004) GRL, Vol. 31, doi:10.1029/2003GL019112.

Hong et al. (2000) Holocene, Vol. 10, 1-7.

Hong et al. (2001) EPSL, Vol. 185, 111-119.

Horiuchi et al. (2008) QG, Vol. 3, 253-261.

Hoyt and Schatten (1993) JGR, Vol. 98, 18895-18906.

Hu et al. (2003) Science, Vol. 301, 1890-1893.

Hubeny et al. (2006) Geology, Vol. 34, 569-572.

Ji et al. (2005) EPSL, Vol. 233, 61-70.

Ji et al. (2009) QSR, in press, doi:10.1016/j.quascirev.2008.12.015.

Kim et al. (2007) Geology, Vol. 35, 387-390.

Knutz et al. (2007) Paleoceanography, Vol. 22, doi:10.1029/2006PA001298.

Kuhlmann et al. (2004) GRL, Vol. 31, doi:10.1029/2004GL021267.

Lamy et al. (2001) EPSL, Vol. 185, 369-382.

Leventer et al. (1996) GSA Bulletin, Vol. 108, 1626-1644.

Lim et al. (2005) QR, Vol. 64, 12-20.

Lund and Curry (2004) Paleoceanography, Vol. 19, doi:10.1029/2004PA001008.

Mangili et al. (2007) QSR, Vol. 26, 1725-1735.

Masson-Delmotte et al. (2004) Holocene, Vol. 14, 145-151.

Mayewski et al. (1997) JGR, Vol. 102, 26345-26366.

McCabe et al. (2008) QI, Vol. 188, 31-40.

McConnell et al. (2007) PNAS, Vol. 104, 5743-5748.

Moros et al. (2006) Paleoceanography, Vol. 21, doi:10.1029/2005PA001214.

Moy et al. (2002) Nature, Vol. 420, 162-165.

Neff et al. (2001) Nature, Vol. 411, 290-293.

Nielsen et al. (2004) Geology, Vol. 32, 317-320.

Nyberg et al. (2001) QR, Vol. 56, 87-102.

Nyberg et al. (2002) PPP, Vol. 183, 25-41.

Patterson et al. (2004a) Sedimentary Geology, Vol. 172, 67-84.

Patterson et al. (2004b) Palaeontologia Electronica, Vol. 7, 1-17.

Peristykh and Damon (2003) JGR, Vol. 108, doi:10.1029/2002JA009390.

Pipin (1999) A\&A, Vol. 346, 295-302.

Polyakov et al. (2003) J. Climate, Vol. 12, 2067-2077.

Poore et al. (2004) GRL, Vol. 31, doi:10.1029/2004GL019940.

Ram and Stolz (1999) GRL, Vol. 26, 1043-1046 (and p. 1763 for correction).

Raspopov et al. (2008) PPP, Vol. 259, 6-16.

Russell and Johnson (2005a) GRL, Vol. 32, doi:10.1029/2005GL023295.

Russell and Johnson (2005b) QSR, Vol. 24, 1375-1389.

Ruzmaikin et al. (2006) JGR, Vol. 111, doi:10.1029/2006JD007462.

Sano et al. (2009) Climate Dynamics, in press, doi:10.1007/s00382-008-0454-y. 
Schimmelmann et al. (2003) Holocene, Vol. 13, 763-778.

Shen et al. (2006) GRL, Vol. 33, doi:10.1029/2005GL024804.

Sicre et al. (2008) EPSL, Vol. 268, 137-142.

Soon (2005) GRL, Vol. 32, doi:101.0129/2005GL023429.

Springer et al. (2008) GRL, Vol. 35, doi:10.1029/2008GL034971.

Stager et al. (1997) $Q R$, Vol. 47, 81-89.

Stuiver et al. (1995) $Q R$, Vol. 44, 341-354.

Swindles et al. (2007) JQS, Vol. 22, 667-679.

Tan et al. (2003) GRL, Vol. 30, doi:10.1029/2003GL017352.

van Beynen et al. (2008) QI, Vol. 187, 76-83.

Vonmoos (2005) Ph.D. thesis, ETH Zurich, Diss. No. 16224.

Vonmoos et al. (2006) JGR, Vol. 111, doi:10.1029/2005JA011500.

Wagner et al. (2001) GRL, Vol. 28, 303-306.

Wang H. et al. (2003) Geology, Vol. 31, 179-182.

Wang Y. J. et al. (2005) Science, Vol. 308, 854-857.

Watanabe et al. (1998) JMSJ, Vol. 76, 447-451.

Watanabe et al. (1999) Polar Meteorology and Glaciology, Vol. 13, 64-74.

Wei et al. (2008) JGR, Vol. 113, doi:10.1029/2008JD010111.

Wiles et al. (2009) GRL, in press, doi:10.1029/2009GL037164.

Wilson et al. (2007) Climate Dynamics, Vol. 28, 425-440.

Wollenburg et al. (2007) PPP, Vol. 255, 195-222.

$\mathrm{Xu}$ et al. (2006) PPP, Vol. 230, 155-164.

Yiou et al. (1997) JGR, Vol. 102, 26441-26454.

Yu and Ito (1999) Geology, Vol. 27, 263-266.

Zhang P. Z. et al. (2008) Science, Vol. 322, 940-942.

Zhong et al. (2007) JQS, Vol. 22, 659-665.

Acronyms employed: $A \& A=$ Astronomy \& Astrophysics; $E P S L=$ Earth and Planetary Science Letters; G3 = Geochemistry, Geophysics, Geosystems; GRL = Geophysical Research Letters; GSA = Geological Society of America; JGR = Journal of Geophysical Research; JMSI = Journal of the Meteorological Society of Japan; JQS = Journal of Quaternary Science; PNAS = Proceedings of the National Academy of Sciences of the USA; PPP = Palaeogeography, Palaeoclimatology, and Palaeoecology; $Q G=$ Quaternary Geochronology; $Q I=$ Quaternary International; $Q R=$ Quaternary Research; $Q S R=$ Quaternary Science Reviews. 